\title{
Benthic trophic dynamics in California coastal basin and continental slope communities inferred using inverse analysis
}

\author{
Peter M. Eldridge, George A. Jackson \\ Department of Oceanography, Texas A \& M University, College Station, Texas 77843, USA
}

\begin{abstract}
The isolation of the deep-sea benthos makes it difficult to measure more than a few elemental transformation rates in a given ecosystem. The measurements usually made include the transfer rates of such biologically important materials as oxygen, particulate carbon, and ammonia between water and sediment. We have developed inverse analysis techniques that produce descriptions which include material flows between trophic groups within the sediments. The techniques use a limited set of process rate and biomass measurements and known physiological and chemical information. Estimated material flows include rates of consumption, production, respiration, excretion, and egestion of the major trophic groups in benthic food webs. We analyzed benthic communities in a lowoxygen environment (Santa Monica Basin) and in a higher-oxygen environment on the continental slope (Patton Escarpment), both bordering southern California (USA). The inverse analyses suggested that the low oxygen community was dominated by anaerobic protozoa and bacteria and supported only a small populations of grazers. The dominance of bacteria with high growth rates caused sedimentary detrital carbon and nitrogen there to decompose in a few days. The Patton Escarpment community, overlain with oxygen-rich water, had a more complex food web dominated by the higher trophic level protozoa, meiofauna, and macrofauna. We suggest that carbon and nitrogen were retained in the biomass of these larger grazers for months. The analyses showed that grazers and microbial organisms specialize in using resources of different nutritional quality. Specialization of this type may have led to a more complete oxidation of sedimenting detritus at Patton Escarpment than at Santa Monica Basin. Organisms in both food webs had low gross production efficiencies that averaged $10 \%$ at the Patton Escarpment and $7 \%$ at the Santa Monica Basin sites. These results suggest that inverse analysis can be a powerful tool to analyze benthic communities.
\end{abstract}

\section{INTRODUCTION}

The isolation of the deep-sea benthos has made measurement of trophic interactions in benthic communities difficult. Our understanding of community metabolism is mostly based on estimates of transfer rates for such chemical species as oxygen, nitrate, and sulfate between sediment and overlying water and of sedimentation rates for particles falling out of the water column. Knowledge of such fluxes provides little detail about such ecosystem properties as organisms present, the efficiency with which they process detrital sediments, or their interactions with each other.

The typical benthic community respires (oxidizes) particulate organic carbon (POC) falling from the water column to fuel biotic metabolisms. Some organisms, such as deposit feeders, ingest sedimentary detritus directly; others filter particulate matter from overlying waters; still others, such as ciliates, protozoa, and kinorhynchs, feed on fellow benthic organisms as well as detritus. Measures of gross community metabolism derived from oxidant fluxes provide little information about flows of energy and nutrients within the benthic community.

Degradation of organic matter within the sediments can be complicated by a shortage of oxidants. Oxygen is the preferred electron acceptor, providing higher biomass yields from metabolizing organic matter than any of the other oxidants (e.g. Zehnder \& Stumm 1988). Nitrate, sulfate, and other, less-preferred compounds 
provide the needed oxidation power in its absence. These oxidants move into the benthos from overlying waters by the relatively slow process of molecular diffusion and by localized animal ventilation. As they move down the sediment column, the oxidants are depleted in order of decreasing energy yield. Oxygen is removed first, sometimes being completely removed within $1 \mathrm{~cm}$ of the sediment-water interface. Nitrate is removed in the next deeper region, with removal of sulfate and other oxidants occurring in still deeper sediment regions. The resulting benthos in a region of plentiful food and low overlying dissolved oxygen concentrations consists of a series of layers, each of which has organisms adapted to use the locally dominant oxidant. The dominant oxidants usually occur in the vertical order of oxygen, nitrate, manganese, ferric iron, and sulfate (Zehnder \& Stumm 1988).

While organisms within each layer are kept isolated from those in other layers by the changing chemical environments, their communities do interact with each other. Some organisms feed in more than one layer. Large organisms can physically mix several layers in a process known as bioturbation. As a result, below the sediment-water interface there is a complex set of sediment communities within which energy and material flow in patterns not discernible from the gross oxidant fluxes that we know how to measure (Jørgensen 1977).

Measurements of geochemical fluxes do provide information about the net oxidant consumption which must be interpreted carefully because of unobserved cycling occurring within the sediments. For example, a sulfate molecule which is reduced to sulfide in a deep sedimentary layer can be oxidized back to sulfate if it should move into an oxidant-rich $\left(\mathrm{Fe}^{3+}, \mathrm{Mn}^{4+}, \mathrm{NO}_{3}{ }^{-}, \mathrm{O}_{2}\right)$ layer (Jørgensen 1983). Nitrate reduced to ammonia can itself be oxidized to nitrite or nitrate in the presence of $\mathrm{O}_{2}$. Thus, net oxidant movements at the sediment-water interface are not related simply to total oxidant consumption within the underlying sediments.

It has been difficult to develop quantitative descriptions of benthic food webs because so few of the complex network of coupled redox reactions involved are usually measured. Similar difficulties in understanding the ecosystem have been encountered in the description of planktonic food webs when only a few rates are known. Vézina \& Platt (1988) overcame this limitation by using an inverse analysis technique to estimate trophic flows. Their approach used a least-squares algorithm to determine a complete set of food web flows that were consistent with measured flows and with ancillary information. It provided a data analysis tool in which field observations were combined with general ecological and physiological data to estimate flows through the entire food web. The method has been extended and applied to other planktonic systems (Ducklow et al. 1989, Jackson \& Eldridge 1992). We discussed early results in applying the inverse approach to the benthos at Santa Monica Basin (Eldridge \& Jackson 1992), but did not describe the method that we used in detail.

Our goal in this paper is to describe an inverse method capable of analyzing the diverse benthic habitats of the southern California coastal margin. We characterize the flows of carbon and nitrogen through benthic communities as in Eldridge \& Jackson (1992) but add capacities to deal with the energetics of aerobic heterotrophs, chemoautotrophs, and anaerobic organisms. We work with a simplified food web in which species are lumped into groups, also referred to as trophic groups or compartments, which denote their functional roles in benthic communities. The amounts of energy and material that pass between the trophic groups are constrained by efficiencies of heterotrophic and chemoautotrophic processes and by mass conservation. The description resulting from the analysis includes material flows, measured and inferred, between food web compartments. We examine 2 regions, with high and with low oxygen concentrations in overlying waters, to contrast how organic substrates can be used in these different redox environments.

\section{METHODS}

Inverse analysis. Energy for the benthic community is supplied by a particulate flux from the water column. Organisms convert it to 3 types of energy-rich chemical forms: particulate organic matter (living or detrital), dissolved organic matter, and reduced inorganic compounds. These materials are used by benthic grazers, heterotrophic bacteria, and chemoautotrophic bacteria. We subdivided these faunal groups by size and by the energy resource used into grazers - macrofauna, meiofauna, aerobic protozoa, and anaerobic protozoaand bacteria - aerobic and anaerobic heterotrophic bacteria, and chemolithotrophic bacteria. We further subdivided anaerobic heterotrophic bacteria into denitrifying, iron-reducing, and sulfate-reducing bacteria and chemolithotrophic bacteria into nitrifying, iron-oxidizing, and sulfide-oxidizing bacteria. Each bacterial group of the food web can be identified by the chemical substrates from which it obtains energy and oxidants (Table 1). The result of this sorting is a description of the benthic food web in terms of organism group (compartment), each with a particular chemical or trophic identity

Interactions between food web compartments are described by the rates of material flows between them and by the chemical reactions they use to fuel their metabolisms. Reduced carbon flows can be thought of 
Table 1. Species key for Figs. 3 to 8

\begin{tabular}{|lll|}
\hline $\begin{array}{l}\text { Bacteria } \\
\text { Chemoautotrophs }\end{array}$ & \\
& B1 & Nitrification $\mathrm{NH}_{3} \rightarrow \mathrm{NO}_{2}^{-}$ \\
B2 & Nitrification $\mathrm{NO}_{2}^{-} \rightarrow \mathrm{NO}_{3}^{-}$ \\
B3 & Ferrous iron oxidation \\
B4 & Sulfide oxidation \\
Aerobic heterotrophs & \\
B5 & Oxygen-utilizing bacteria \\
& \\
Anaerobic heterotrophs & \\
B6 & Nitrate-reducing \\
B7 & Sulfate-reducing \\
B8 & Ferric-reducing \\
& \\
Grazers & \\
& G1 & Microfauna (Anoxic tolerant) \\
G2 & Microfauna \\
G3 & Meiofauna \\
G4 & Macrofauna \\
\end{tabular}

as surrogates for energy flows; organic nitrogen flows can be considered surrogates for the nutritional aspects of food. We solved for rates of carbon and nitrogen flows between compartments and for important rates of oxidant supply, consumption, and regeneration (Appendix 1). The collected values for all of the flows can be considered as a vector for which we are trying to solve the inverse problem. Experimental measurements of elemental flows from the water column or to burial below the community provided the data input for a specific benthic system, as did any information about biomasses of the different compartments. Additional information about the relationships among different flows came from known efficiencies for production, respiration, and egestion as well as from biomass-dependent allometric relationships for physiological rates.

We made several simplifying assumptions for this analysis. No member of a compartment could consume organisms from the same or larger size groups. Only heterotrophic bacteria assimilated dissolved organic carbon and nitrogen (DOC and DON). Grazer organisms fed only on particulate matter, either detritus or another organism. Macrofauna and meiofauna fed on all forms of bacteria including anaerobic forms.

While we accounted for different chemical pathways, we did not totally separate out the different oxidant communities because they intermingle in the sediments. Sulfate reduction occurs in microniches of oxidized marine sediments (Jørgensen 1977); denitrification dominates near aerobic interfaces where nitrification processes often provide oxidants (Kristensen \& Blackburn 1978). Sulfate reduction in sediments has occasionally been found co-occurring with aerobic metabolism (Thode-Andersen \& Jørgensen 1989) and in bacterial mats (Canfield 1991a).

Chemoautotrophic bacteria respired aerobically in the model. They are known to respire using nitrate, ferric iron, or manganese on rare occasions (Hooper 1989, Jørgensen 1989). Because these oxidants are themselves formed in reactions with $\mathrm{O}_{2}$, the net result is similar to an aerobic chemoautotrophic respiration at a low efficiency.

Nitrate reduction (denitrification) produced molecular nitrogen $\left(\mathrm{N}_{2}\right)$ in this model, although it is known that nitrate reduction can terminate with the production of nitrous oxide or ammonia (Stouthamer 1988). All $\mathrm{NH}_{3}$ production (regeneration) in this simplified analysis is from degradation of organic matter.

Formulation of the food web. At steady state, the sum of all flows of an element into a compartment equals the sum of the flows out of the compartment. When a protozoan eats a bacterium composed of biomass having a known $\mathrm{C}: \mathrm{N}$ ratio, the $\mathrm{C}$ and $\mathrm{N}$ flows expressing this have the same $C: N$ ratio. Such fixed $\mathrm{C}: \mathrm{N}$ ratios for flows can be expressed using equations. In addition, linear equations can be written using the various elemental flows that express the results of benthic fluxes measured at a given site. The set of all these equations partially defined our system.

Fluxes are related to each other and to available biomass through such physiological relationships as assimilation efficiency, production efficiency, and respiration per unit biomass. These relationships exist within bounded ranges that can be expressed using inequality relationships. Data about biomass abundances are particularly useful for an inverse analysis because they can be used to place bounds on organism respiration, fecal, and excretion rates. The collection of equations and inequalities define the system mathematically. A complete description of our equality and inequality relationships is in the appendix (Appendix 2).

The formulation of various efficiencies, allometric relations, and carbon-nitrogen relationships have been discussed for plankton systems (Vézina \& Platt 1988, Jackson \& Eldridge 1992).

We expressed production efficiencies of chemolithotrophic bacteria using known efficiencies for utilization of chemical substrates (Baas-Becking \& Parks 1927). The driving force for redox processes is given by the Gibbs free energy $(\Delta G)$, only part of which is actually available to an organism (e.g. Stumm \& Morgan 1981). For example, oxidation of sulfide by $\mathrm{O}_{2}$ releases $752.6 \mathrm{~kJ} \mathrm{~mol}^{-1} \mathrm{C}$ in natural waters, while the reduction of $\mathrm{CO}_{2}$ to $\mathrm{CH}_{2} \mathrm{O}$ requires $500.6 \mathrm{~kJ} \mathrm{~mol}^{-1} \mathrm{C}$ (e.g. Stumm \& Morgan 1981). If the conversions were $100 \%$ efficient, a bacterium oxidizing sulfide would reduce 1.5 moles (752.6/500.6) of carbon for every mole of 
sulfide used. Because sulfide oxidation is at most $6 \%$ efficient, there is no more than about 0.1 mole of net bacterial production per mole of sulfide oxidized (Fenchel \& Blackburn 1979, Kelly 1989).

The maximum net production efficiency for this case was formulated as follows:

$$
C_{\mathrm{co}, \mathrm{b} 4} \geq 0.1 S_{\mathrm{s} 2, \mathrm{~s} 3}
$$

where $C_{\mathrm{co}, b 4}$ is the assimilation rate of $\mathrm{CO}_{2}$ by sulfideoxidizing chemolithotrophic bacteria and $S_{\mathrm{s} 2, s 3}$ is their sulfide oxidation rate. The net production efficiencies of the other chemoautotrophic processes were formulated in a similar fashion (Appendix 2).

Solving the problem. We solved the inverse problem by using a procedure which produces a vector with the minimum sum of squared flows that is consistent with all equations and inequality relations (Hanson \& Haskell 1982). Because nitrogen flows are smaller than those of carbon, the technique preferentially decreases carbon flows while it increases nitrogen flows when both types are expressed in molar units. We have multiplied all $\mathrm{N}$ flows by the Redfield $C: N$ ratio (6.6) to express them as $\mathrm{C}$ equivalents during the computations to give $\mathrm{C}$ and $\mathrm{N}$ flows equivalent weights. The result of the procedure is the flow vector with the minimum Euclidean length that satisfies the equations subject to the constraints specified by the inequalities.

We have used the subroutine LSEI (Haskell \& Hanson 1981, Hanson \& Haskell 1982), available in the SLATEC subroutine library (Argonne National Laboratories, Argonne, IL, USA). This subroutine allows sets of equations which are approximate as well as those that are precisely true. Such equations can be used to express the results of field measurements which may have an error or variability associated with them. More complete descriptions of the calculation procedure have been presented in Vézina \& Platt (1988) and in Lawson \& Hanson (1974).

Data. We analyzed benthic communities at 2 sites, one in the Santa Monica Basin (SMB; 33 $44^{\prime} \mathrm{N}$, $118^{\circ} 51^{\prime} \mathrm{W}$ ), where there is little oxygen in the bottom water $(<10 \mu \mathrm{M})$, and the other on the Patton Escarpment ( $\mathrm{PE}_{i} 32^{\circ} 35.7^{\prime} \mathrm{N}, 120^{\circ} 32.1^{\prime} \mathrm{W}$ ), where bottom water oxygen concentrations are typically higher $(138 \mu \mathrm{M})$. Both sites are part of the California Current system and are below relatively productive surface waters, with the bottom depth equal to $900 \mathrm{~m}$ at SMB and $3700 \mathrm{~m}$ at PE.

The types of data collected at the 2 sites differed. Jahnke (1990) measured fluxes of total $\mathrm{CO}_{2}\left(\mathrm{TCO}_{2}\right)$, $\mathrm{Si}(\mathrm{OH})_{4}$, and oxidants $\mathrm{O}_{2}, \mathrm{NO}_{3}{ }^{-}$, and $\mathrm{SO}_{4}{ }^{2-}$, as well as particulate $\mathrm{C}$ deposition and sediment burial rates at $\mathrm{SMB}$. The only oxidant flux rates available from PE were for $\mathrm{O}_{2}$ and $\mathrm{NO}_{3}$ (Smith et al 1983, Reimers \& Smith 1986). There were more biomass data available for PE than for SMB. However, the biomass data from PE did not fit directly into the species groupings used in this model because they were based on organism size. For example, organisms larger than $2 \mu \mathrm{m}$ included bacterial aggregates and yeast-like cells as well as protozoa. We used Snider et al.'s (1984) ternary diagrams of nanobiota composition to estimate microfaunal biomass from the available data. This yielded only an approximate value of the biomass for each compartment because the data used by Snider et al. (1984) came from more oligotrophic benthic communities. Particulate organic carbon flux to the bottom and sediment oxygen demand did not balance at PE (Smith 1987), although sediment trap data did balance oxidant flux data at SMB (Jahnke 1990).

Model adjustment. The initial inverse analysis of the $\mathrm{PE}$ benthic food web showed that over one-third of the oxygen entering the benthos oxidized $\mathrm{S}^{2-}, \mathrm{NH}_{3}, \mathrm{NO}_{2}{ }^{-}$. and $\mathrm{Fe}^{2+}$ in chemoautotrophic processes. Sulfide oxidation was the largest oxygen flow $\left(343 \mu \mathrm{mol} \mathrm{m} \mathrm{m}^{-2} \mathrm{~d}^{-1}\right)$. Significant oxygen flows also went to nitrite oxidation. As a result, there were large recirculating flows between coupled redox pairs $\left(170 \mu \mathrm{mol} \mathrm{S} \mathrm{m}{ }^{-2} \mathrm{~d}^{-1}\right.$ to sulfide and then back to sulfate). Because oxygen is the electron acceptor for the chemoautotrophic processes, much of the $\mathrm{O}_{2}$ in this analysis was diverted from heterotrophic to chemoautotrophic processes.

Although coupled redox reactions do occur in nature (Tiedje 1988), the rates initially suggested by this model were excessive and would have resulted in strong redox gradients in a sediment profile where the sulfate gradient was actually weak (Reimers \& Smith 1986). The high rates occurred because the analysis did not fully consider the differences among energy yields for aerobic and different anaerobic metabolisms. $\Delta \mathrm{G}$ provides a maximum potential yield, but the actual efficiency of biologically mediated redox systems varies considerably. For example, $\Delta G$ from nitrate reduction $\left(-411 \mathrm{~kJ} \mathrm{~mol}^{-1} \mathrm{C}\right)$ is not much less than that of oxygen $\left(-452 \mathrm{~kJ} \mathrm{~mol}^{-1} \mathrm{C}\right.$, assuming carbon as $\mathrm{CH}_{2} \mathrm{O}$ and conditions similar to $\mathrm{PE}$ ), but the observed production efficiency for bacterial denitrification is only $60 \%$ of that for aerobic respiration (Stouthamer 1988). We needed to favor more energetic oxidant flows in the order of $\mathrm{O}_{2}, \mathrm{NO}_{3}{ }^{-}, \mathrm{Fe}^{3-}, \mathrm{SO}_{4}{ }^{2-}$

We did this by preferentially minimizing the largest flows. Just as earlier we scaled nitrogen flows to carbon equivalents, we scaled oxidants flows within the calculation program by factors which were larger for less-preferred oxidants. We experimented with many combinations of factors for $\mathrm{O}_{2}, \mathrm{NO}_{3}^{-}, \mathrm{Fe}^{3+}$, and $\mathrm{SO}_{4}{ }^{2-}$, finding that factors of $1,3,9$, and 27 produced reasonable results for these oxidant flows. For example, scaling only the sulfate reduction rate $\left(S^{b 7}{ }_{s 3,52}\right)$ by a factor of 27 caused the calculated rate to decrease 


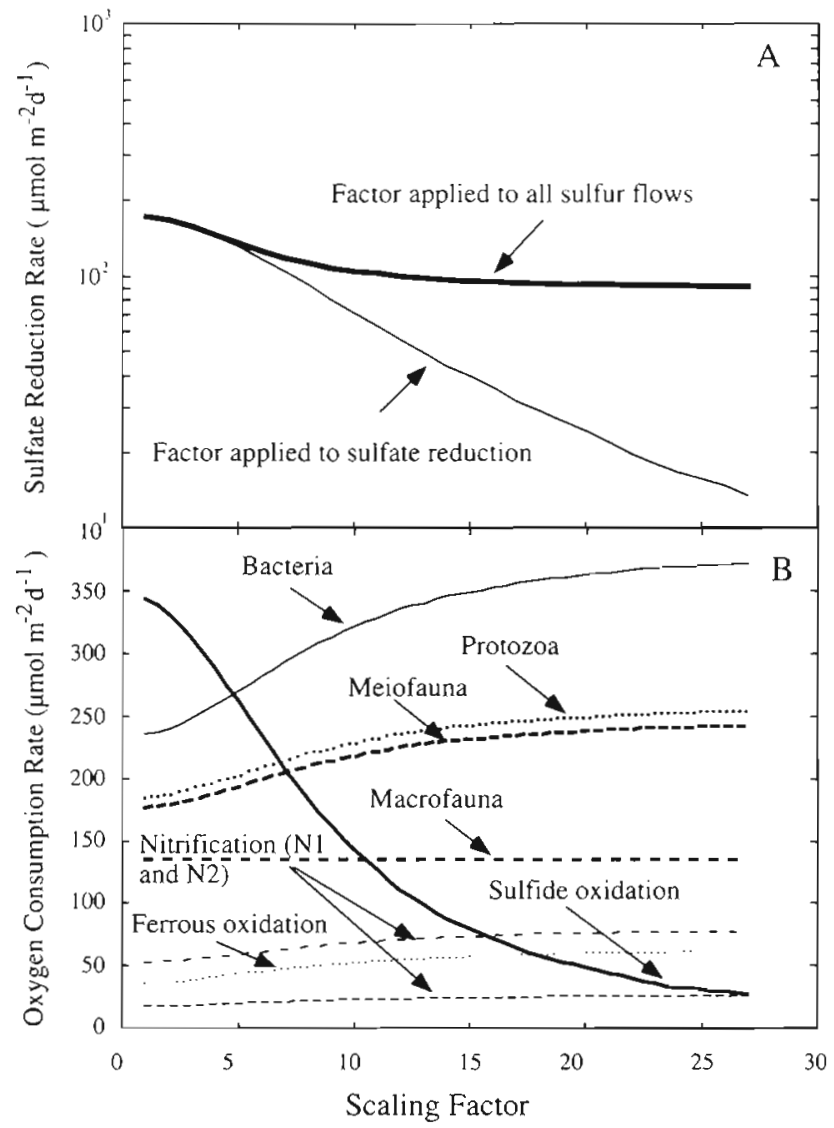

Fig. 1. (A) Effect of a scaling factor for sulfate reduction on selected food web flows. This type of scaling was used as a means of compensating for the difference in energetics of the electron acceptors. Using the scaling factor on the sulfate reduction flow alone was more effective in reducing sulfur flow sizes than was using the scaling factor on all the sulfur flows. (B) Change in the rate of oxygen consumption by each trophic group as a function of the sulfate flow multiplier. The group of heterotrophic aerobic bacteria, the most metabolically active compartment, was affected most by this multiplication while the macrofauna were least affected. The other chemolithotrophic bacteria were also unaffected by the scaling

from 172 to $13 \mu \mathrm{mol} \mathrm{m} \mathrm{m}^{-2} \mathrm{~d}^{-1}$ (Fig. 1A). When the same factor was applied to all sulfur flows $\left(S^{b 7}{ }_{s 3, s 2,}, S^{b 42, s 3}\right.$, $S_{\mathrm{s} 2 \text {, fes, }} S_{\left.w_{c}, s_{3}\right)}$, sulfate reduction rate changed to $91 \mu \mathrm{mol}$ $\mathrm{m}^{-2} \mathrm{~d}^{-1}$ (see Appendix 1 for notation).

Scaling only the sulfate reduction rate changed oxygen consumption with an effect that was greatest on the most metabolically active components (Fig. 1B). Oxygen consumption by aerobic bacteria increased the most, followed by that of protozoa and meiofauna. The change in oxygen consumption by the chemoautotrophic bacteria was small and that by macrofauna was unaffected.

We tested the effect of benthic $\mathrm{O}_{2}$ flux at PE by imposing values ranging from 1200 to $100 \mu \mathrm{mol} \mathrm{m} \mathrm{m}^{-2} \mathrm{~d}^{-1}$ (Fig. 2A). The total aerobic metabolism rate increased

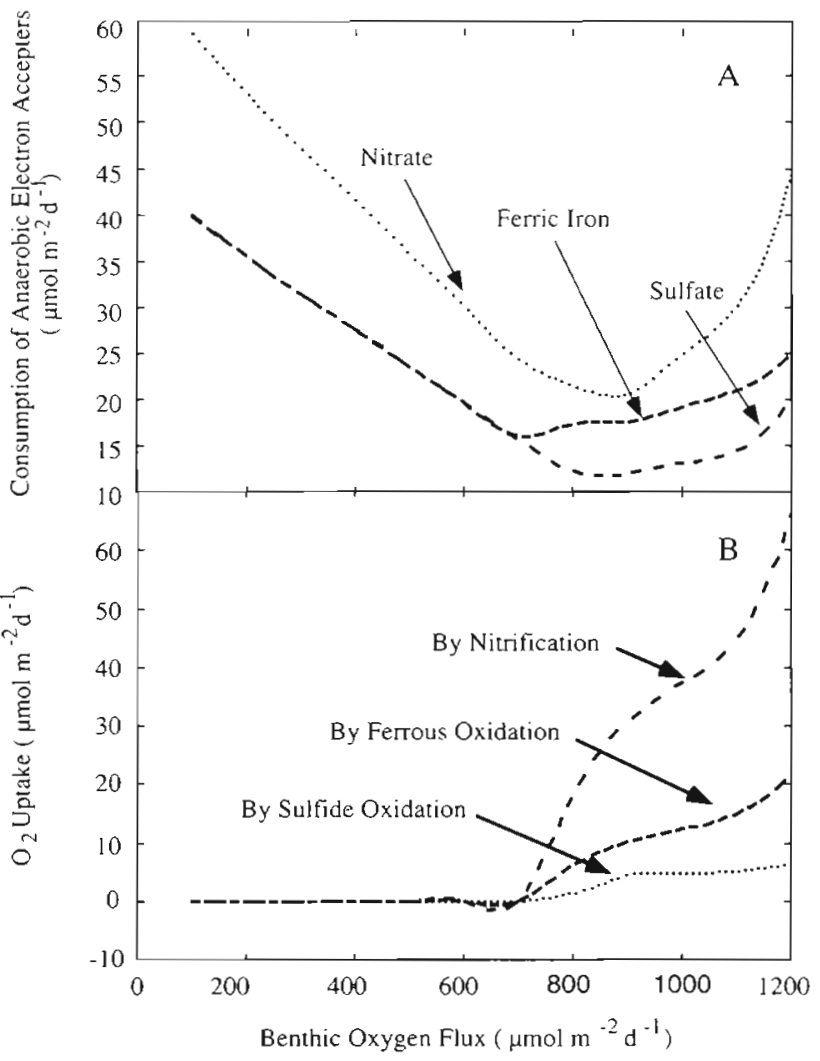

Fig. 2. Estimated flux rates of anaerobic electron acceptors as a function of oxygen transport from the water column. $\mathrm{O}_{2}$ transport was changed while leaving carbon consumption constant. (A) Consumption of anaerobic electron acceptors. Nitrate became the dominant electron acceptor at low $\mathrm{O}_{2}$ flux rates. Nitrate again became the dominant electron acceptor as a result of coupled redox reactions at high $\mathrm{O}_{2}$ transport rates. (B) Consumption of $\mathrm{O}_{2}$ by chemoautotrophic processes. Because of oxygen reduction by chemolithotrophs, nitrate, sulfate and ferric iron reduction increased at high $\mathrm{O}_{2}$ fluxes

as benthic $\mathrm{O}_{2}$ flux increased, reducing the flux of anaerobic oxidants needed to metabolize the organic benthic flux. $\mathrm{NO}_{3}{ }^{-}$and $\mathrm{SO}_{4}{ }^{2-}$ were the least and most changed of the anaerobic oxidant flows. $\mathrm{Fe}^{3+}$ consumption was intermediate at benthic $\mathrm{O}_{2}$ fluxes between 700 and $1200 \mu \mathrm{mol} \mathrm{m} \mathrm{m}^{-2} \mathrm{~d}^{-1}$ and as high as those of $\mathrm{SO}_{4}{ }^{2-}$ at lower $\mathrm{O}_{2}$ fluxes. At benthic flux rates greater than $900 \mu \mathrm{mol} \mathrm{m} \mathrm{m}^{-2} \mathrm{~d}^{-1}$, more $\mathrm{O}_{2}$ arrived than was needed to support aerobic heterotrophic processes. The excess $\mathrm{O}_{2}$ was used to restore $\mathrm{N}, \mathrm{Fe}$, and $\mathrm{S}$ to their oxidized states (Fig. 2A, B). About $20 \%$ of the total sedimentation oxygen went to re-oxidation of the reduced inorganic species at $1200 \mu \mathrm{mol} \mathrm{O} \mathrm{O}^{-2} \mathrm{~d}^{-1}$, similar to the fraction estimated by Reimers \& Smith (1986).

Sensitivity to model parameters. We tested effects of data variability on the analysis by increasing and decreasing the value of each datum individually by $20 \%$. The sensitivity of the model to these 
changes was determined by calculating measures $\left(A_{c}\right.$ and $A_{n}$ ) of relative grazer carbon and nitrogen metabolism:

$$
A_{c}=\frac{C_{\mathrm{gr}}}{C_{\mathrm{T}}} \quad \text { (3) } \quad A_{\mathrm{n}}=\frac{N_{\mathrm{gr}}}{N_{\mathrm{T}}}
$$

where $C_{\mathrm{gr}}$ and $C_{\mathrm{T}}$ are summed grazer and total community respirations and $N_{\text {gr }}$ and $N_{\text {T }}$ are summed grazer ammonia excretion and total community nitrogen regeneration. These are measures of the balance between the bacteria and the grazers in community metabolism. Because there is no growth in this steadystate analysis, respiration is a good measure of an organism's use of its organic resources and, by extension, is a useful measure of the entire community's performance. All other pathways of $\mathrm{C}$ and $\mathrm{N}$ that lead through compartments are simply transformations of organic material.

A sensitivity index $S(X, p)$ measured the change in a variable $X$ relative to a change in the parameter $p$ (Fasham et al. 1990):

$$
S(X, p)=\left(\frac{\left(X(p)-X_{\mathrm{s}}\right)}{X_{\mathrm{S}}}\right)\left(\frac{\left(p-p_{\mathrm{s}}\right)}{N_{\mathrm{T}}}\right)^{-1}
$$

where $p_{\mathrm{s}}$ and $p$ are the standard and changed parameter values and $X_{\mathrm{s}}$ and $X(p)$ are the standard and changed values of $X$. We calculated $S$ using $A_{c}, A_{n}$ and individual food web flows. If $S$ is zero, $X$ does not change with $p_{\text {; }}$ if $S$ is 1, a $20 \%$ increase in $p$ causes a $20 \%$ increase in $X$. For $S>1, X$ is disproportionately large relative to a change in the parameter.

Simulated tracer analysis. The flow out of a compartment can be expressed as the compartment biomass abundance times a kinetic rate constant. This constant can be used to calculate the rate at which a simulated tracer would move through the food web at steady state (e.g. Jackson \& Eldridge 1992). We calculated kinetic rate constants for those compartments where biomass values existed using flows derived from the inverse approach. Because there were biomass estimates at SMB only for the macrofauna, we assumed specific growth rates to calculate biomass of the other compartments. Specific growth rates of $0.36,0.096$ and $0.0481 \mathrm{~d}^{-1}$ were calculated using the allometric equation of Platt et al. (1984), average cell carbon per cell (Rowe 1983, Reimers \& Smith 1986, Børsheim \& Bratbak 1987), and growth efficiencies (Fenchel \& Blackburn 1979, Cammen 1989) for bacteria, microfauna, and meiofauna. The tracer consisted of bacterial biomass. The fraction of tracer allocated to each of the 8 bacterial compartments was the fraction of the total bacterial respiration it respired as estimated by the inverse method
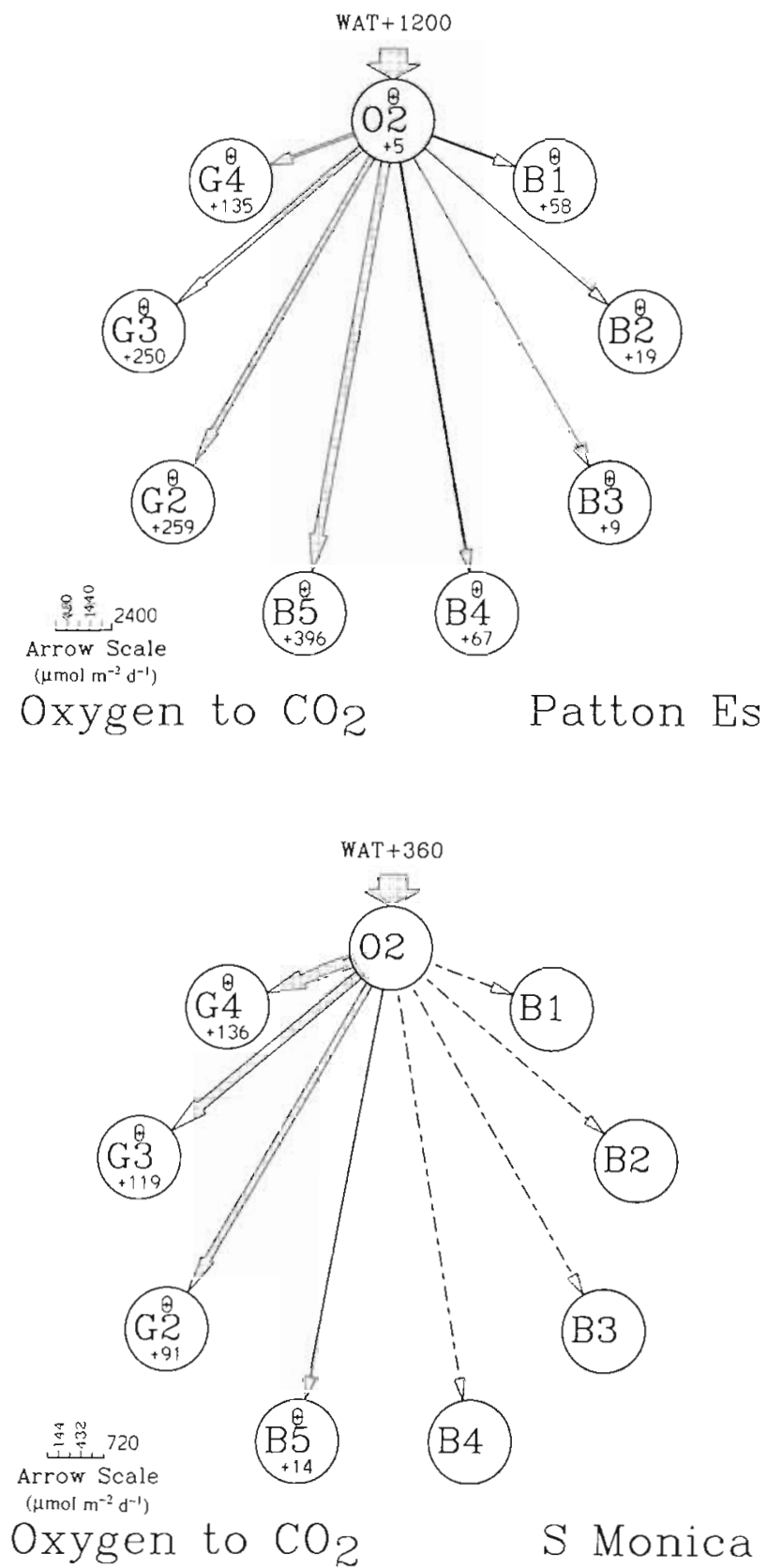

Fig. 3. Oxygen utilization by benthic organisms. At PE, grazer compartments used $54 \%$ of the oxygen. Most of this was consumed by the protozoan and meiofauna populations. About $33 \%$ of the oxygen was used by the bacteria and $13 \%$ by the chemolithotrophic bacteria. Arrows indicate possible material flows: dashed arrows indicate zero flows, solid arrows indicate positive material flows. The width of a solid arrow is proportional to the relative rate of material flow. Symbols are defined in Table 1. Number under a label indicates the difference between inputs and outputs to a compartment. If there is no number, the inputs balance outputs. At SMB, $96 \%$ of the oxygen was used by the aerobic grazer populations and $4 \%$ by the bacteria. About one third as much oxygen entered $\mathrm{SMB}$ as entered the $\mathrm{PE}_{;}$the rate for nitrate and sulfate fluxes were much higher at SMB 


\section{MODEL RESULTS}

\section{Oxygen fluxes}

$\mathrm{PE}$ and $\mathrm{SMB}$, with high and low oxygen concentrations in their overlying waters, represent quite different ecological situations. Sediment $\mathrm{O}_{2}$ demands reflected this difference, being $1200 \mu \mathrm{mol} \mathrm{m} \mathrm{m}^{-2} \mathrm{~d}^{-1}$ at $\mathrm{PE}$ and $360 \mu \mathrm{mol}$ $\mathrm{m}^{-2} \mathrm{~d}^{-1}$ at SMB. Oxygen consumption patterns were quite different at these sites, not only in total rates but also in which organism groups dominated. Heterotrophic bacteria, chemoautotrophic bacteria and grazers used 33,13 and $54 \%$ of the $\mathrm{O}_{2}$ benthic flux in the PE simulation. Of the $\mathrm{O}_{2}$ used by the grazers, microfauna, meiofauna and macrofauna used 40,40 and 20\% (Fig. 3).

In the SMB analysis, grazer and heterotrophic bacteria populations consumed 96 and $4 \%$ of the $\mathrm{O}_{2}$ benthic flux (Fig. 3). Protozoa, meiofauna and macrofauna used 26,35 and $39 \%$ of grazer consumption.

\section{Carbon flows}

Carbon that enters a benthic food web through sedimentation was either respired as $\mathrm{CO}_{2}$ or buried. The burial rate at $\mathrm{PE}$ was fixed by field data but the sedimentation rate was derived from the analysis. The derived sedimentation rate was $1243 \mu \mathrm{mol} \mathrm{C} \mathrm{m}^{-2} \mathrm{~d}^{-1}$, of which $9 \%$ was buried and the balance respired by grazers ( $52 \%$ ), aerobic bacteria (32\%) and anaerobic bacteria ( $7 \%$ ). Microfauna and meiofauna were the most active grazers, each respiring about $20 \%$ of the sedimenting detritus (Fig. 4).

A larger fraction (26\%) of the $3670 \mu \mathrm{mol} \mathrm{C} \mathrm{m} \mathrm{C}^{-2}$ falling to the benthos in the SMB simulation was permanently buried. Anaerobic bacteria and grazers dominated benthic metabolism. Anaerobic bacteria consumed the most carbon, respiring $62 \%$ of the metabolized fraction; anaerobic grazer, aerobic grazers and aerobic bacteria respired 25, 12 and $1 \%$ of the rest (Fig. 4).

Anaerobic bacteria accounted for $20 \%$ of total bacterial C respiration at $\mathrm{PE}$ but $99 \%$ at SMB (Fig. 5). Respiration by anaerobic protozoa was $<1 \%$ of total grazer respiration at $\mathrm{PE}$ but $65 \%$ at $\mathrm{SMB}$. Anaerobic C

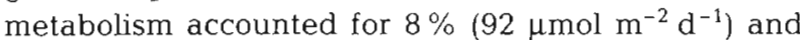
$87 \%\left(2340 \mu \mathrm{mol} \mathrm{m} \mathrm{m}^{-2} \mathrm{~d}^{-1}\right)$ of total $\mathrm{C}$ metabolism in the PE and SMB analyses. Denitrification and sulfate reduction were the dominant anaerobic process in both analyses, each accounting for nearly half $(42 \%$ denitrification vs $49 \%$ sulfate reduction) of the anaerobic bacterial $\mathrm{C}$ respiration at $\mathrm{PE}$ while denitrifying bacteria respired slightly more carbon at SMB (55 vs $39 \%$ ). Ferric-iron reduction by bacteria accounted for about $5 \%$ in both simulations.
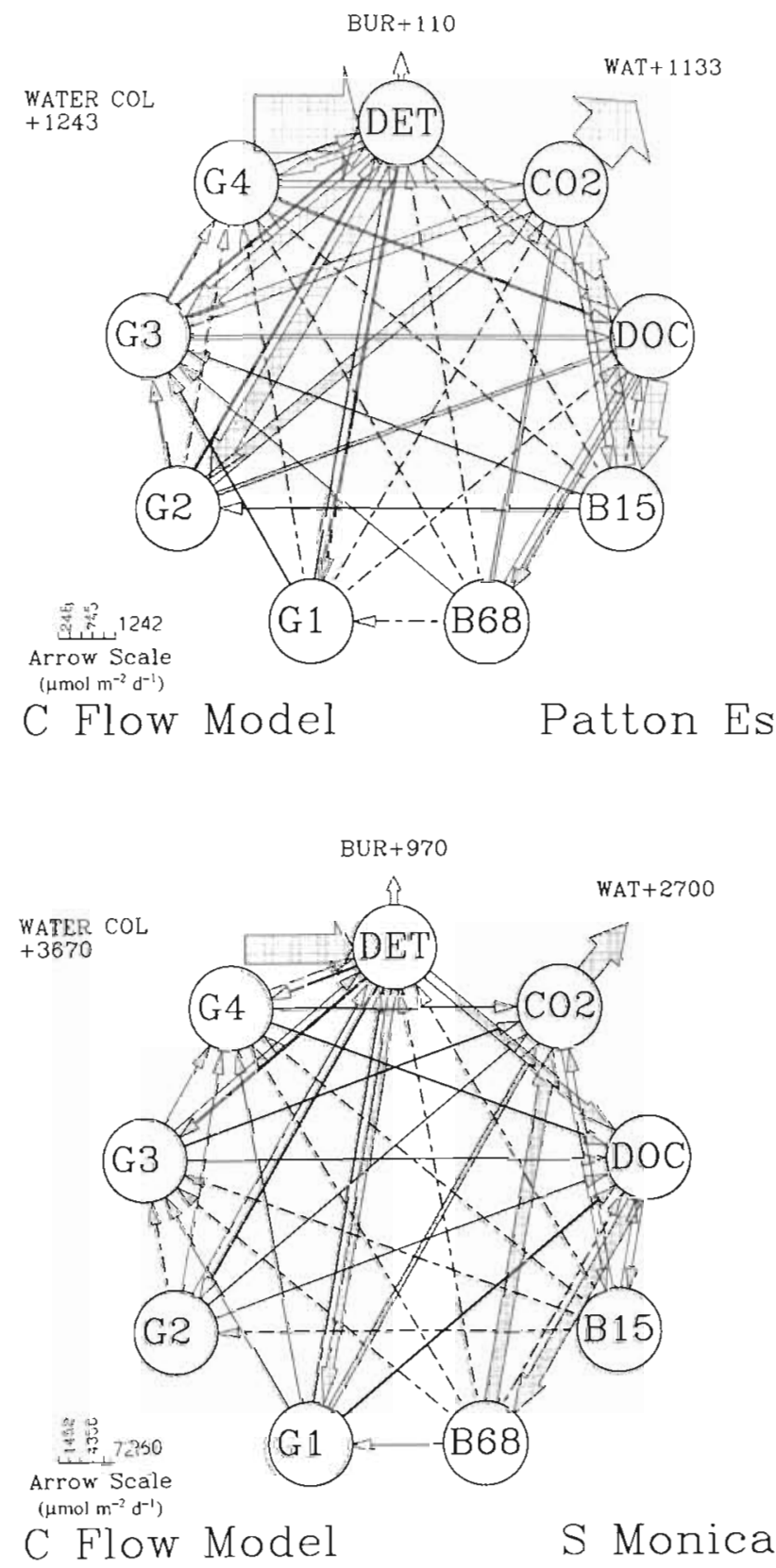

Fig. 4. Overall carbon flows. At PE, carbon oxidation was dominated by aerobic grazers and bacteria. Grazers and aerobic bacteria respired 57 and $35 \%$ respectively of the community respiration. Anaerobic processes account for only $8 \%$ of total carbon respiration. At SMB, carbon oxidation was dominated by anaerobic bacteria and grazers. Anaerobic bacteria respired $62 \%$ of the carbon entering the food-web. The anaerobic grazer respired $25 \%$ of the entering carbon, while the aerobic grazers respired $12 \%$ of the remaining carbon

Detritus was the major food source for the protozoa, meiofauna and macrofauna in both simulations. Only about $15 \%$ of the carbon consumed by these grazers at $\mathrm{PE}$ and SMB was in the form of other trophic compartments. 

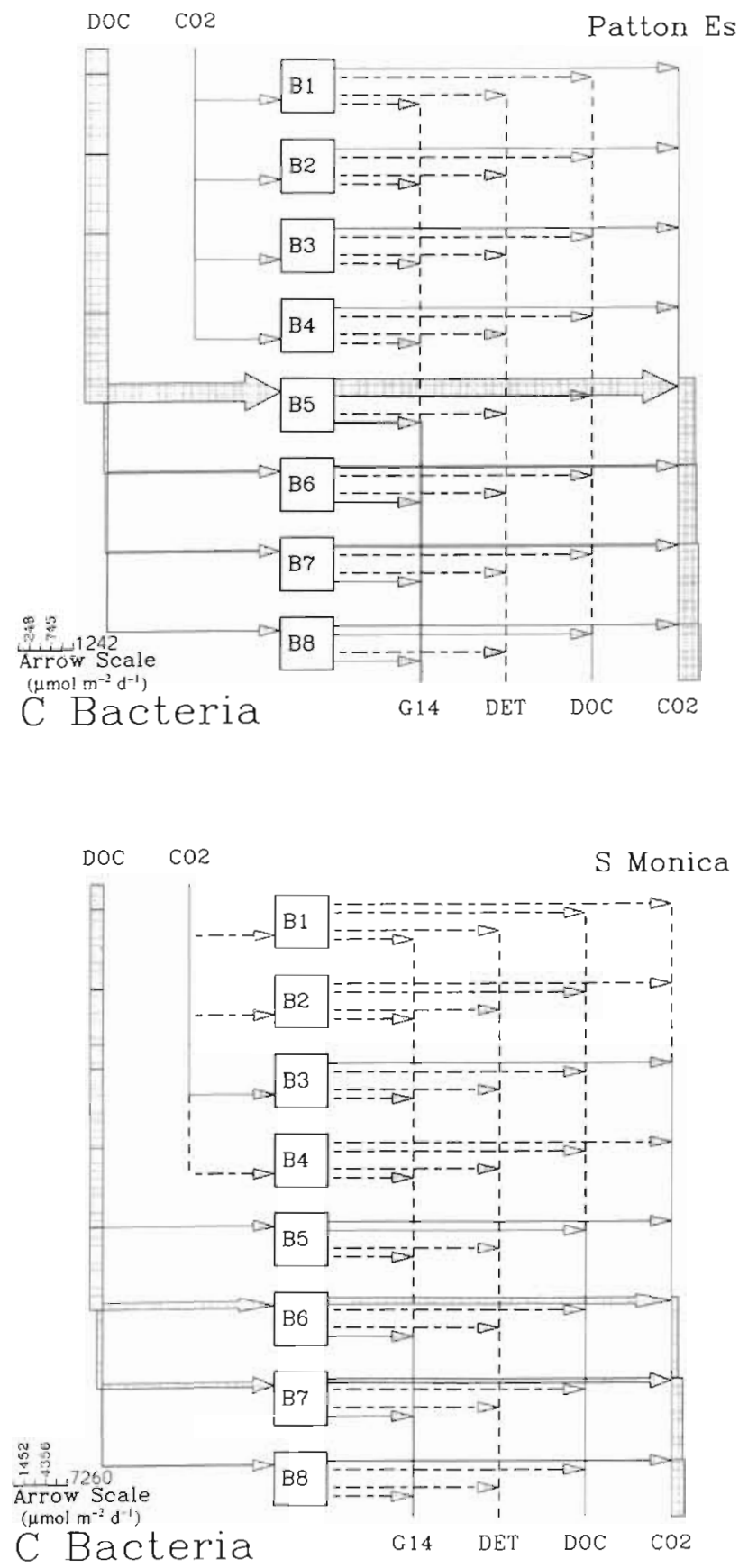

Fig. 5. Carbon flow through bacteria. At PE, most carbon entered the bacteria as a dissolved organic carbon (DOC). The heterotrophic aerobic bacteria used $81 \%$ of the DOC at $\mathrm{PE}$. The anaerobic denitrifying and sulfate-utilizing bacteria each assimilated $8 \%$ of the DOC even though there was little nitrate or sulfate entering the benthos at the sediment-water interface. At SMB, there was no chemolithotrophic utilization of carbon. All the carbon entered the bacteria in a dissolved organic form (DOC). The heterotrophic aerobic bacteria used only $1 \%$ of the DOC while the denitrifying bacteria assimilated $55 \%$ of the DOC. Sulfate-utilizing bacteria were also active using $40 \%$ of the DOC flux

\section{Nitrogen flows}

Nitrogen flows through the PE food web were dominated by aerobic grazers; those flows at SMB were dominated by anaerobic groups (Fig. 6). Anaerobic flows accounted for $38 \%$ of the total $117 \mu \mathrm{mol} \mathrm{N}$ $\mathrm{m}^{-2} \mathrm{~d}^{-1}$ regenerated at $\mathrm{PE}$ and $60 \%$ of the $304 \mu \mathrm{mol}$ $\mathrm{m}^{-2} \mathrm{~d}^{-1}$ regenerated at SMB. Total nitrogen regenera-
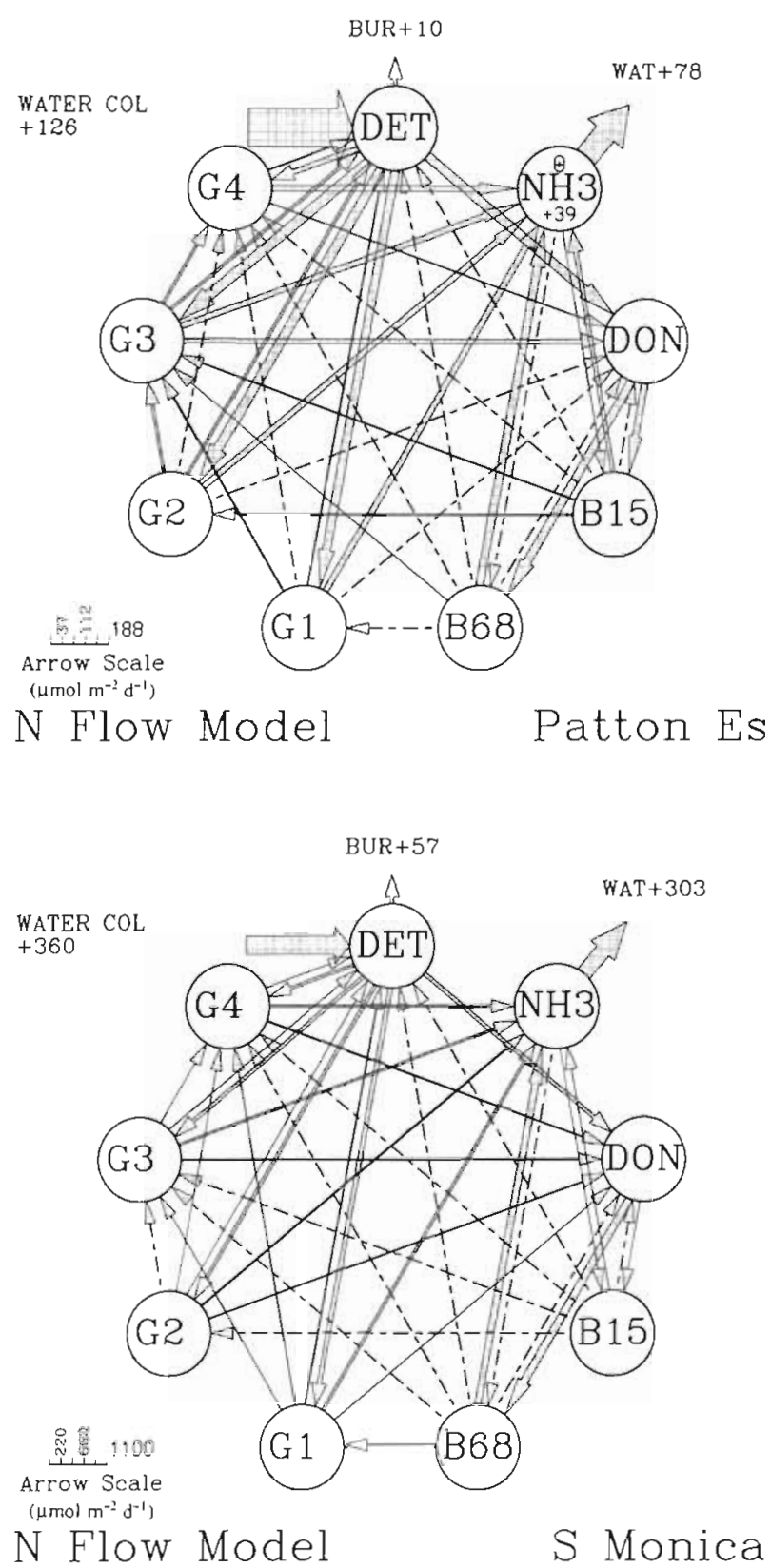

Fig. 6. Nitrogen flows. At PE, major flows are similar to the carbon flow description; $66 \%$ of ammonia production was by grazer organisms. At $\mathrm{SMB}, 60 \%$ of ammonia production is by anaerobes 
tion through anaerobic grazers was about $15 \%$ at both $\mathrm{PE}$ and SMB.

The major nitrogen food source for the grazers at both sites was detritus. At the PE site, $22 \%$ of the total grazer consumption of $143 \mu \mathrm{mol} \mathrm{N} \mathrm{m}^{-2} \mathrm{~d}^{-1}$ was by bacteria-to-grazer or grazer-to-grazer feeding. The same flows at SMB constituted about $15 \%$ of the total $316 \mu \mathrm{mol} \mathrm{m} \mathrm{m}^{-2} \mathrm{~d}^{-1}$ grazer consumption.

The high nitrification rate at $\mathrm{PE}$ resulted in about $33 \%$ of the regenerated nitrogen $\left(\mathrm{NH}_{3}\right)$ oxidizing to nitrate. Denitrification converted $40 \%$ of the $126 \mu \mathrm{mol}$ $\mathrm{N} \mathrm{m}^{-2} \mathrm{~d}^{-1}$ benthic flux to $\mathrm{N}_{2}$ (Fig. 7). The water column was the source of all $\mathrm{NO}_{3}^{-}$for denitrification at $\mathrm{SMB}$ (Fig. 7) because there was no benthic nitrification there.

Sulfate- and iron-reducing bacteria were also regenerators of ammonia. The activation of this ammonia-producing pathway at PE depended on the recycling of sulfur and iron by chemoautotrophic oxidation (Fig. 8); the oxidants came from the water column at SMB (Fig. 8). Although the proportion of ammonia produced through denitrification and sulfate reduction was about the same at SMB (14 vs $17 \%)$, denitrification regenerated less ammonia than did sulfate reduction at PE ( 8 vs $12 \%$ ). About $11 \%$ of the ammonia at $\mathrm{SMB}$, and less than $2 \%$ at $\mathrm{PE}$, was produced by ferric-reducing bacteria.

\section{Carbon and nitrogen relationships}

Detritus consumed by grazers at $\mathrm{PE}$ had an average $C: N$ ratio of 8.4 , compared to the average sedimentary detritus composition there of 9.9. The lower value suggests that grazers fed selectively on material containing more nitrogen. Grazer biomass typically has a C: $N$ ratio of 5.0 (Rowe 1983, Fenchel \& Finlay 1991). To achieve this ratio, grazers retained relatively more nitrogen than carbon and consumed nitrogen-rich bacteria.

Bacteria consumed DOM with a $C: N$ ratio of 11.0 at $P E$. To maintain their biomass at a $C: N$ ratio of 5 , bacteria respired and excreted relatively more carbon than nitrogen (Table 2).

Bacteria at SMB assimilated DOM at a $\mathrm{C}: \mathrm{N}$ ratio of 11.7 , a value higher than in detritus entering from the water column. Permanently-buried detritus was carbon rich, with a $\mathrm{C}: \mathrm{N}$ ratio of 17 that was established from field data. These burial flows were balanced by $\mathrm{N}$-rich flows to grazers, yielding a low $C: N$ value of 6.3 for detritus consumed by grazers. Grazers appeared to feed selectively on nutritious detrital fractions at this site also. Grazers respired organic matter with a $C: N$ ratio of 6.0 , much lower than the bacterial respiration $C: N$ ratio
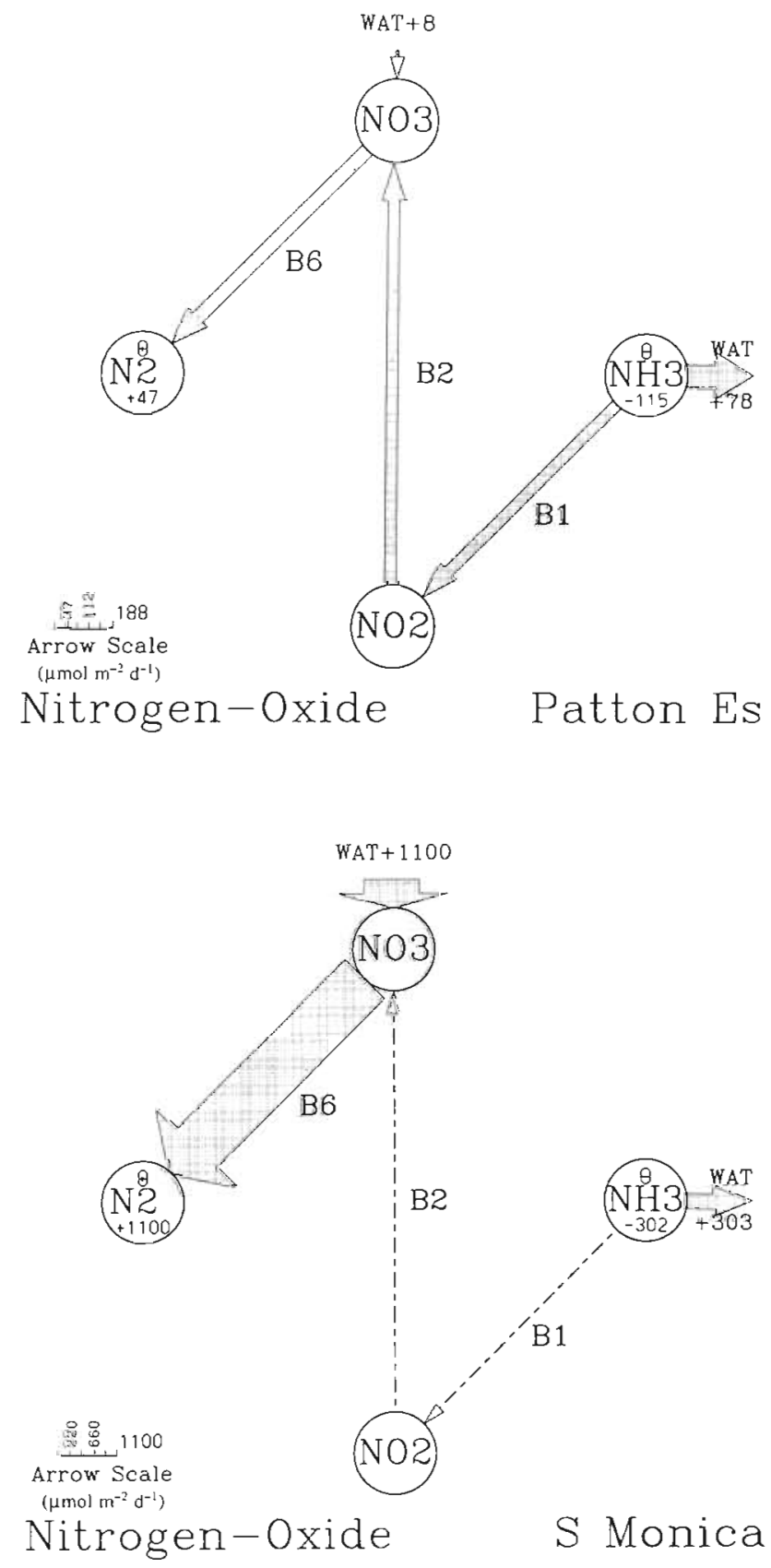

Fig. 7. Nitrification and denitrification. At PE, about $40 \%$ of the ammonia was used in denitrification; the rest went to the water column. The large flux of nitrate from nitrification provided an electron acceptor for denitrification. At SMB, there was no nitrification. Flows for denitrification were, however, large, as indicated by the large measured flux of nitrate across the water-sediment interface

of over 12. As a result of their preferential consumption of nitrogen-rich detritus, grazers in the SMB analysis were the major nitrogen regenerators even though they processed less carbon than did the bacteria. 

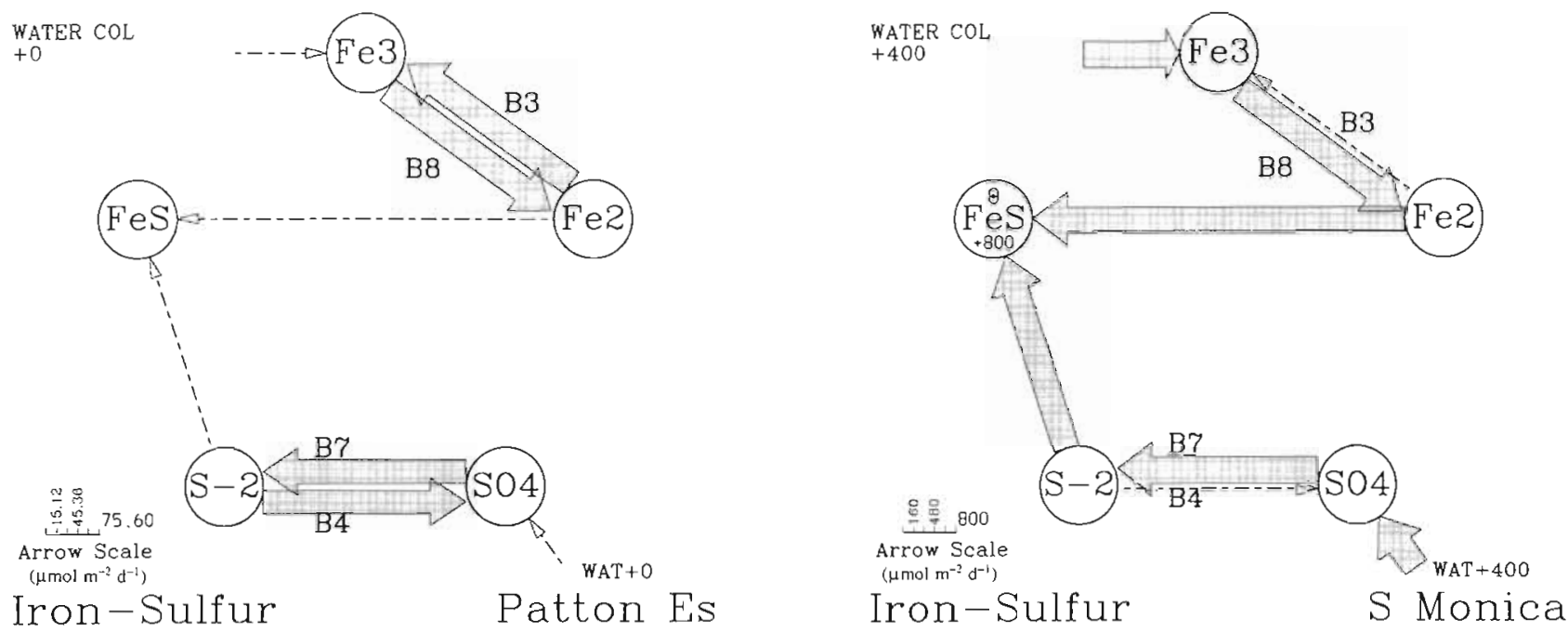

Fig. 8. Sulfur and iron redox reactions. At PE, the sulfide-sulfate redox reactions restored oxidant used in sulfate metabolism. At SMB, because of the absence of chemolithotrophic reactions, the reduced ferrous iron formed pyrite

\section{Sensitivity analysis}

The PE results for $S\left(A_{c_{1}} p\right)$ and $S\left(A_{n}, p\right)$ were relatively insensitive to small changes in the measured fluxes; the SMB results were moderately sensitive only to changes in benthic fluxes of $\mathrm{O}_{2}$ and $\mathrm{TCO}_{2}$ (Table 3). The benthic $\mathrm{O}_{2}$ flux provided the only oxidant that grazers other than the anaerobic protozoa could use. Changes in its already small value at SMB affected the ratio with which ammonia was released by the microbial and grazer components of the food web, although the change was relatively smaller than the change in $\mathrm{O}_{2}$ flux. $\mathrm{TCO}_{2}$ flux had the largest relative effect on $S\left(A_{c}, p\right)$ at $\mathrm{SMB}$ but, again, the change was relatively smaller than the change in $\mathrm{TCO}_{2}$ flux. Fractional changes in biomass had no effect at SMB while changes in macrofaunal biomass caused changes in flows from macrofauna to detritus and to DOC producing a sensitivity index of 1 for those flows.

Imposed $\mathrm{C}: \mathrm{N}$ ratios provided important linkages between $\mathrm{C}$ and $\mathrm{N}$ flows that had to be met. The analyses were moderately sensitive to changes in the $C: N$ ratio of the organisms (Table 3$)$, with $S\left(A_{n}, p\right)$ between 0 and 0.3 relative response to a change in the parameters. Fractional changes in the $\mathrm{N}$ : $\mathrm{C}$ ratio caused similar or greater changes in macrofauna and meiofauna DON production but not in the same flows for carbon. Sensitivity indexes were $>3$ for these nitrogen flows, but only 0.2 for the carbon flows. Larger values for the nitrogen sensitivity parameter suggest that nitrogen flows may be less constrained in our analyses than carbon (Table 3). DOC consumption by ferric-oxidizing bacteria was most sensitive to changes in the above parameters at $\mathrm{PE}$ ( $S$ mean $=1.8$ ) while DOC consumption by aerobic bacteria was most sensitive to changes in parameters at $S M B(S$ mean $=0.8)$. The aerobic bacteria flow was

Table 2. Carbon and nitrogen flows in the Patton Escarpment (high oxygen) and Santa Monica Basin (low oxygen) food webs. Material flows are in $\mu \mathrm{mol} \mathrm{m} \mathrm{m}^{-2} \mathrm{~d}^{-1}$. Species as in Table 1. DIM: dissolved inorganic matter; DOM: dissolved organic matter; DET: detritus; SED: sedimentation; BUR: burial; WC: water column

\begin{tabular}{|lrrrrrr|}
\hline \multirow{2}{*}{ Flow } & \multicolumn{3}{c}{ Patton Escarpment } & \multicolumn{3}{c|}{ Santa Monica Basin } \\
& $\mathrm{C}$ & $\mathrm{N}$ & $\mathrm{C}: \mathrm{N}$ & $\mathrm{C}$ & $\mathrm{N}$ & $\mathrm{C}: \mathrm{N}$ \\
\hline DIM to B1-8 & 5 & 0.4 & 13.3 & 4 & 1.3 & 3.1 \\
B1-8 to DIM & 493 & 39.5 & 12.5 & 1693 & 136.7 & 12.4 \\
G1-4 to DIM & 645 & 77.1 & 8.4 & 1012 & 167.8 & 6.0 \\
B1-8 to DOM & 4 & 0.0 & - & 2 & 0.0 & - \\
G1-4 to DOM & 213 & 19.2 & 11.1 & 566 & 77.3 & 7.3 \\
B1-8 to DET & 0 & 0.0 & - & 0 & 0.0 & - \\
G1-4 to DET & 123 & 24.6 & 5.0 & 193 & 38.6 & 5.0 \\
DET to DOM & 325 & 29.8 & 10.9 & 1206 & 73.5 & 16.4 \\
DOM to B5-8 & 541 & 49.0 & 11.0 & 1773 & 150.9 & 11.7 \\
B6-8 to G1 & 0 & 0.0 & - & 83 & 15.5 & 5.3 \\
B1-5 to G2 & 28 & 5.6 & 5.0 & 0 & 0.0 & - \\
B1-8 to G3 & 22 & 4.2 & 5.2 & 0 & 0.0 & - \\
B1-8 to G4 & 0 & 0.0 & - & 0 & 0.0 & - \\
G to G & 112 & 22.4 & 5.0 & 163 & 32.6 & 5.0 \\
SED to DET & 1243 & 126.1 & 9.9 & 3670 & 360.0 & 10.2 \\
DET to G & 931 & 111.2 & 8.4 & 1688 & 268.2 & 6.3 \\
DET to BUR & 110 & 9.7 & 11.3 & 970 & 57.0 & 17.0 \\
DIM to WC & 1132 & 77.8 & 14.0 & 2700 & 303.0 & 8.9 \\
\hline
\end{tabular}


Table 3. Parameter sensitivity. Model was run at parameter values $p \pm 2$ of the standard case. The $\mathrm{C}$ and $\mathrm{N}$ (grazer: community) respiration sensitivity parameters, $S\left(A_{C}, p\right)$ and $S\left(A_{N}, p\right)$, show normalized response to changes in data $p+(1.2$ of the normal value); and $p-(0.8$ of normal parameter value). If $S=1$, a $20 \%$ change in the data lead to a $20 \%$ change in the result. (See text for details). Biomass and fluxes have units of $\mathrm{mM} \mathrm{m}^{-1}$ or $\mathrm{mM} \mathrm{m}^{-1} \mathrm{~d}^{-1}$. Species as in Table 1

\begin{tabular}{|c|c|c|c|c|c|}
\hline \multirow[t]{2}{*}{$\begin{array}{l}\text { Parameter } \\
\qquad(p)\end{array}$} & \multirow[t]{2}{*}{ Value } & \multicolumn{4}{|c|}{$\begin{array}{l}\text { Normalized sensitivity of } \mathrm{CO}_{2} \\
\text { and ammonia production }\end{array}$} \\
\hline & & $S\left(A_{C}, p-\right)$ & $S\left(A_{C}, p+\right)$ & $S\left(A_{N}, p-\right)$ & $S\left(A_{\mathrm{N}}, p+\right)$ \\
\hline \multicolumn{6}{|c|}{ Patton Escarpment } \\
\hline $\mathrm{O}_{2}$ flux & 1.2 & -0.07 & -0.05 & 0.00 & 0.00 \\
\hline $\mathrm{NO}_{3}$ flux & 0.05 & 0.00 & 0.00 & 0.00 & 0.00 \\
\hline C burial & 0.11 & 0.00 & 0.00 & -0.01 & -0.01 \\
\hline C sedim. & $\geq 0.26$ & 0.00 & 0.00 & 0.00 & 0.00 \\
\hline $\mathrm{N}$ sedim. & $\geq 0.03$ & 0.00 & 0.00 & 0.00 & 0.00 \\
\hline Bacteria & 0.37 & 0.00 & 0.00 & 0.00 & 0.00 \\
\hline Microfauna & 12.42 & 0.00 & 0.00 & 0.00 & 0.00 \\
\hline Meiofauna & 2.4 & 0.00 & 0.00 & 0.00 & 0.00 \\
\hline Macrofauna & 2.4 & 0.06 & 0.06 & 0.00 & 0.00 \\
\hline$B 1(N: C)$ & 0.20 & -0.05 & 0.06 & 0.03 & 0.11 \\
\hline $\mathrm{B} 2(\mathrm{~N}: \mathrm{C})$ & 0.20 & -0.04 & 0.06 & -0.24 & 0.06 \\
\hline $\mathrm{B} 3(\mathrm{~N}: \mathrm{C})$ & 0.20 & 0.01 & 0.07 & 0.15 & 0.08 \\
\hline $\mathrm{B} 4(\mathrm{~N}: \mathrm{C})$ & 0.20 & 0.01 & 0.02 & 0.13 & 0.29 \\
\hline $\mathrm{B} 5(\mathrm{~N}: \mathrm{C})$ & 0.20 & 0.04 & 0.05 & 0.17 & -0.08 \\
\hline $\mathrm{B} 6(\mathrm{~N}: \mathrm{C})$ & 0.20 & 0.00 & 0.05 & 0.15 & -0.03 \\
\hline $\mathrm{B} 7(\mathrm{~N}: \mathrm{C})$ & 0.17 & -0.06 & 0.06 & 0.11 & 0.09 \\
\hline $\mathrm{B} 8(\mathrm{~N}: \mathrm{C})$ & 0.20 & -0.11 & 0.04 & 0.06 & 0.14 \\
\hline $\mathrm{G} 1(\mathrm{~N}: \mathrm{C})$ & 0.20 & 0.04 & 0.05 & 0.09 & -0.02 \\
\hline $\mathrm{G} 2(\mathrm{~N}: \mathrm{C})$ & 0.20 & -0.03 & -0.06 & 0.14 & 0.13 \\
\hline $\mathrm{G} 3(\mathrm{~N}: \mathrm{C})$ & 0.20 & -0.13 & -0.07 & -0.09 & -0.20 \\
\hline $\mathrm{G} 4(\mathrm{~N}: \mathrm{C})$ & 0.20 & 0.04 & -0.03 & 0.06 & 0.03 \\
\hline \multicolumn{6}{|c|}{ Santa Monica Basin } \\
\hline $\mathrm{O}_{2}$ flux & 0.36 & 0.04 & 0.01 & 0.27 & 0.06 \\
\hline $\mathrm{NO}_{3}$ flux & 1.1 & -0.08 & -0.10 & -0.03 & -0.04 \\
\hline $\mathrm{SO}_{4}$ flux & 0.4 & -0.07 & -0.02 & -0.04 & -0.01 \\
\hline $\mathrm{TCO}_{2}$ flux & 2.7 & 0.51 & 0.13 & -0.01 & 0.14 \\
\hline C sedim. & 3.67 & -0.03 & -0.02 & 0.19 & 0.18 \\
\hline $\mathrm{N}$ sedim. & 0.36 & 0.00 & 0.00 & 0.00 & 0.00 \\
\hline Macrofauna & 15.0 & 0.00 & 0.00 & 0.00 & 0.00 \\
\hline $\mathrm{B} 1(\mathrm{~N}: \mathrm{C})$ & 0.20 & 0.07 & -0.01 & 0.07 & -0.03 \\
\hline $\mathrm{B} 2(\mathrm{~N}: \mathrm{C})$ & 0.20 & 0.05 & -0.01 & -0.13 & -0.07 \\
\hline B3 $(\mathrm{N}: \mathrm{C})$ & 0.20 & 0.08 & 0.01 & 0.09 & -0.03 \\
\hline $\mathrm{B} 4(\mathrm{~N}: \mathrm{C})$ & 0.20 & 0.10 & -0.02 & 0.15 & -0.10 \\
\hline $\mathrm{B} 5(\mathrm{~N}: \mathrm{C})$ & 0.20 & 0.09 & -0.04 & 0.13 & -0.12 \\
\hline $\mathrm{B} 6(\mathrm{~N}: \mathrm{C})$ & 0.20 & 0.09 & -0.03 & 0.14 & -0.09 \\
\hline $\mathrm{B} 7(\mathrm{~N}: \mathrm{C})$ & 0.17 & 0.03 & -0.04 & 0.02 & -0.11 \\
\hline $\mathrm{B} 8(\mathrm{~N}: \mathrm{C})$ & 0.20 & 0.07 & -0.02 & 0.08 & -0.07 \\
\hline $\mathrm{G} 1(\mathrm{~N}: \mathrm{C})$ & 0.20 & -0.01 & -0.02 & 0.05 & -0.09 \\
\hline $\mathrm{G} 2(\mathrm{~N}: \mathrm{C})$ & 0.20 & 0.02 & 0.00 & 0.02 & -0.03 \\
\hline $\mathrm{G} 3(\mathrm{~N}: \mathrm{C})$ & 0.20 & 0.02 & -0.02 & 0.04 & -0.09 \\
\hline G4 (N:C) & 0.20 & 0.02 & -0.01 & 0.06 & -0.06 \\
\hline
\end{tabular}

small at SMB but was very sensitive to changes in $\mathrm{O}_{2}$ flux to the sediments $(S=10)$. Any difference between oxygen supply and grazer consumption was used by the aerobic bacteria.

Small changes in input data caused smaller changes in the inferred food web flows used in the 2 community sensitivity indices. Small flows such as grazer-to-grazer or bacteria-to-grazer flows were relatively more affected by changes in input data than were large flows. However, a large change in the value of the sensitivity index for a small flow does not represent much of a change in size of that flow.

\section{Simulated tracer}

$\mathrm{C}$ and $\mathrm{N}$ tracers placed initially in the bacterial compartments moved rapidly to other biotic compartments during a 20 d period (Fig, 9). Essentially all the tracer had moved out of the bacteria after $2 \mathrm{~d}$ at PE and $5 \mathrm{~d}$ at $\mathrm{SMB}$. The rapid tracer loss at PE results from a high bacterial turnover rate. We cannot infer much about the bacteria loss rates at SMB because we assumed kinetic rate constants to calculate biomass for this analysis. More than twice the $\mathrm{C}$ tracer and 4 times the $\mathrm{N}$ tracer remained in the grazer compartments at $\mathrm{PE}$ than at SMB after $20 \mathrm{~d}$. $\mathrm{C}$ and $\mathrm{N}$ tracer accumulated more rapidly and reached higher concentrations in the protozoa than in any other grazer groups at either site. The maximum percent concentration in the protozoa was reached on Day 2 at PE and Day 5 at SMB.

There was no obvious transfer of C-tracer to other grazers from the protozoa similar to the transfer to protozoa from bacteria. Instead, most of this tracer was respired (Figs. $9 \& 10$ ). Even though bacteria composed the same small fraction of the grazer diet, tracer accumulated much more rapidly to higher concentration in the PE grazer biomass. This supports a view of the PE food web as having an underlying trophic linkage through which microbial biomass is exploited that is not present in the SMB food web. Most of the carbon in both $\mathrm{PE}$ and $\mathrm{SMB}$ food webs was converted to $\mathrm{CO}_{2}$, which should eventually move back to the water column; only $8 \%$ at $\mathrm{PE}$ and $3 \%$ at SMB of the carbon tracer remained in the combined grazer compartments (Fig. 9A, B) while $20 \%$ of the $\mathrm{N}$ at PE and $8 \%$ at SMB was retained for $20 \mathrm{~d}$. This difference in retention illustrates the dominance of short-lived bacteria at SMB that turn over carbon and nitrogen on time scales of days and the dominance of longer-living grazers at PE that turn over carbon and nitrogen on times scales of months. It also emphasizes how $\mathrm{N}$ is more conservative than $\mathrm{C}$ within a food web.

\section{DISCUSSION}

Benthic ecosystems respond not only to food supply but also to oxidant environment. Oxygen depletion in the sediments occurs whenever the rate at which a benthic ecosystem consumes organic matter exceeds 


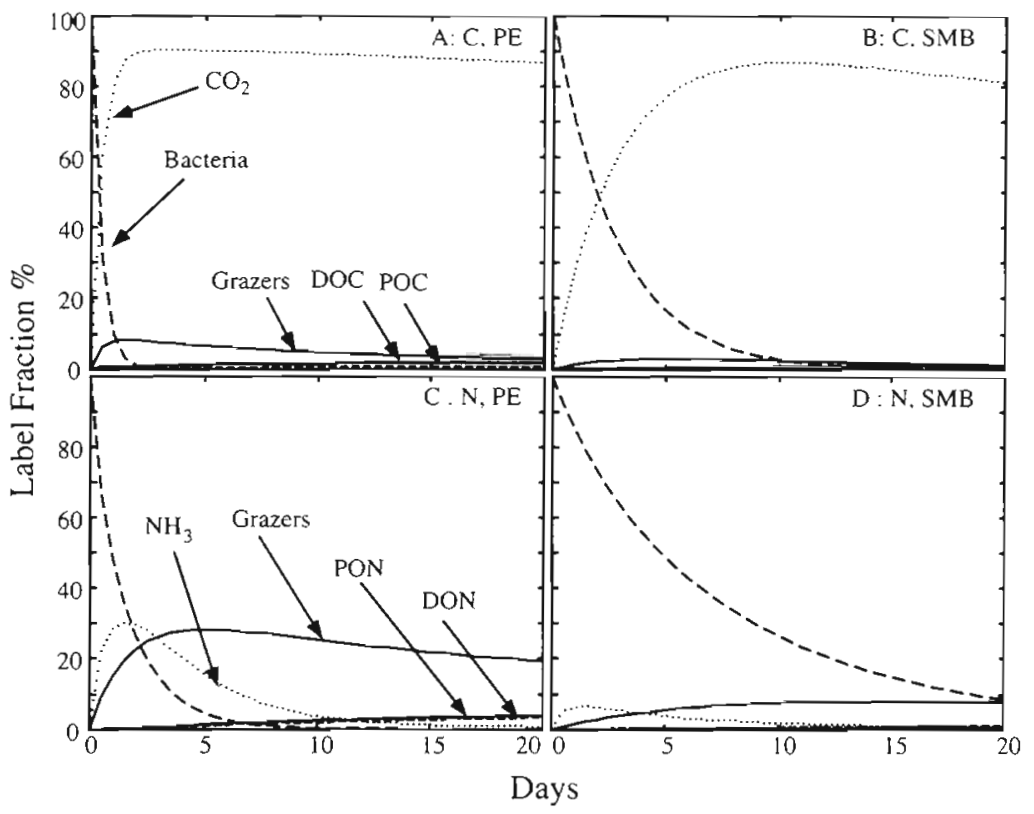

Fig. 9. Distribution of carbon (A \& B) and nitrogen (C \& D) tracer in the food webs. In both food webs most of the carbon was lost to carbon dioxide which went to the water column. Bacteria lost the nitrogen tracer slower than the carbon tracer at both sites. In both cases, little of the carbon tracer ended up in the grazer compartment. This was not true of nitrogen. About $20 \%$ of the nitrogen tracer entered the grazer compartment and was retained over the $20 \mathrm{~d}$ period at $\mathrm{PE}$

the rate at which oxygen flows into it, a condition that tends to occur in oceanic areas with high sedimentation rates and/or low bottom water oxygen concentrations. Both of these situations occur off southern Califormia at the Santa Monica Basin and at the Patton Escarpment. Anoxic sediments extend to within $1 \mathrm{~mm}$ of the seawater interface in Santa Monica and San Pedro Basins (Jahnke 1990); they start several centimeters below the seawater interface at the Patton Escarpment (Reimers \& Smith 1986). The thick oxygencontaining sediments region within Patton Escarpment benthos supports active macrofaunal and meiofaunal populations while the predominant activities in Santa Monica Basin are anaerobic and are mediated mostly by bacteria.

Knowing material flow rates to the various food web groups allows one to determine how fast organisms grow, respire, excrete, produce feces, and die. The inverse method allows us to estimate the essential carbon and nitrogen flows in an aggregated benthic food web from a limited amount of data on the system. This food web description can, in turn, be used to calculate ecological efficiencies and indices that describe the general state of the benthic community. However, the consolidation of species into functional groups for our analysis precludes using the results for speciesbased indices. Any community index calculated using these flows, such as a diversity index, must depend on flow rates to functional groups, not species.

\section{Energy and nutrition}

There are major energetic differences between the ecosystem at $\mathrm{PE}$ and that at $\mathrm{SMB}$. Where there was little oxygen (SMB), a variety of anaerobic bacterial and microfaunal groups oxidized the benthic POC flux; where there was more oxygen (PE), more of the carbon was oxidized by the animal groups. This resulted in a higher bacterial 'diversity' under low oxygen conditions and higher animal 'diversity' under higher oxygen conditions.

Anoxic environments generally have higher burial rates, although the reasons for this are not clear (Lee 1992 and references therein). Mechanisms most often cited for this difference include higher and more complete reaction rates in aerobic communities and higher sedimentation rates in anaerobic communities. However, chemical kinetics alone cannot be responsible because disappearance rates for organic compounds in anaerobic and aerobic microbial communities are very similar in the absence of grazers (Canfield 1991b, Lee 1992). Furthermore, because higher sedimentation rates already have a role in the benthos being anoxic, an additional relationship with deposition is unclear.

Animals could have a significant role in determining burial rates because of their different abundances in the 2 environments (Wishner et al. 1990, Andersen \& Kristensen 1992). Faunal grazers, both by consuming detritus and by stimulating microbial metabolism through bioturbation, may cause more of the freshly sedimenting POC and older, more refractory POC to be oxidized, reducing the amount of carbon ultimately buried (Andersen \& Kristensen 1992). Lee (1992) has suggested that most of the buried material is bacterial biomass which is undegraded in the absence of grazers

When comparing burial and reaction kinetics, certain distinctions need to be made. Carbon that is buried is the residue, the fraction of material that is not oxidized in its passage through the biologically active zone. This fraction depends on the transformation rate of this material and on the length of time that the transformation takes place. Longer reaction times can compensate for slower reaction kinetics. The flows with which we have worked are not reaction rates, although the kinetic rates can be estimated if one knows the carbon pool size. 


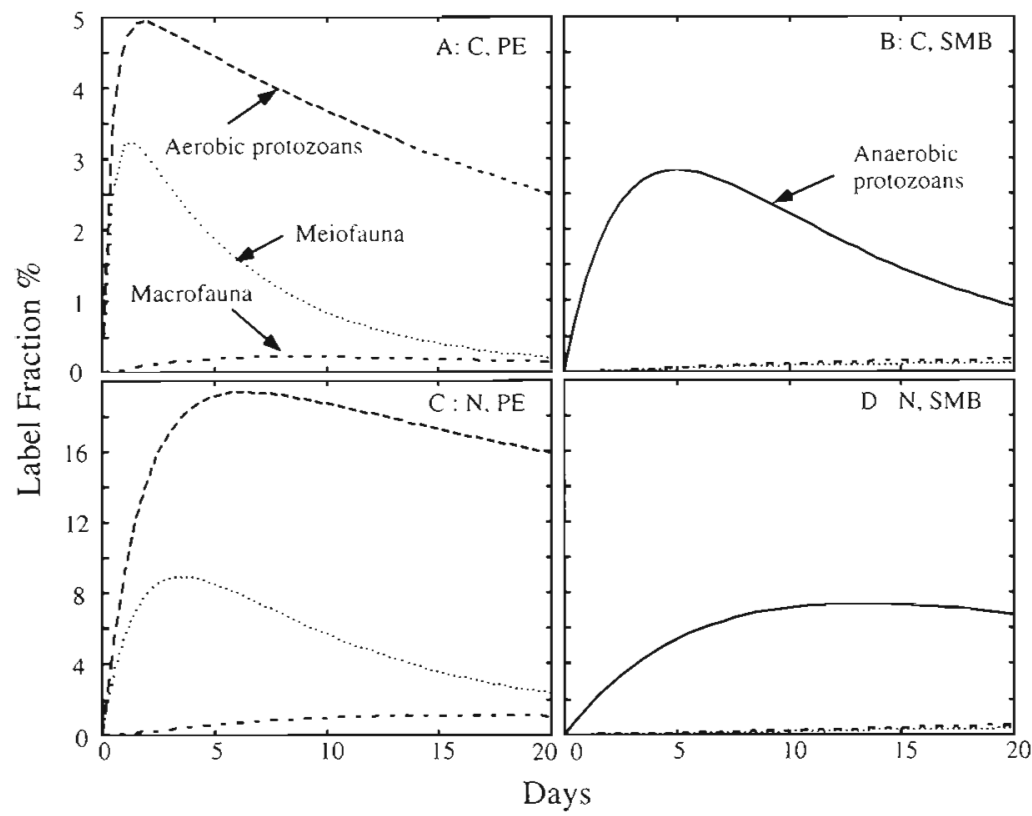

Fig. 10. Distribution of tracer carbon (A\& B) and nitrogen $(C \& D)$ in the grazer compartments. More than twice as much carbon tracer and 4 times the nitrogen tracer entered the grazer compartment at $\mathrm{PE}$, a benthic site, than at SMB. Carbon and nitrogen tracer at both sites accumulated more rapidly and reached higher concentrations in the protozoans than in any of the other grazer compartments

There was a greater fraction of settling carbon buried at SMB (26\%) than at PE (9\%). Benthic grazers fed directly on detritus at both sites, with bacteria providing a negligible amount $(5 \%)$ of their daily consumption. This small fraction is consistent with results from studies of benthic organisms (Wetzel 1977, Carey \& Mayer 1990). It does not support the idea that carbon deposition in oxic environments is low because of grazer consumption of bacteria. Most carbon oxidation at SMB (62\%) was by bacteria. Most benthic respiration at $\mathrm{PE}(>57 \%$ of sedimenting material) was by grazers. In neither case did our results show large flows of bacteria to the detritus or to grazers.

The conclusion that larger grazers at PE and SMB used detritus with a higher nitrogen content than do microbial organisms follows from the fact that $\mathrm{N}: \mathrm{C}$ of the flows from detritus to grazers were 1.2 to 1.6 times that of their ratio in detritus. Selection may occur by particle sorting in the feeding apparatus, by feeding in richer deposits (Carey \& Mayer 1990) or, possibly, by feeding on freshly sedimented material. Preferential nitrogen removal could be related to the lower energy needed to break a $\mathrm{C}-\mathrm{N}$ bond relative to a $\mathrm{C}-\mathrm{C}$ bond (Toth \& Lerman 1977). The tracer analysis also showed that bacteria respire more C than N. About 15 to $20 \%$ of nitrogen originally bacterial biomass in the tracer analysis but less than $7 \%$ of the $\mathrm{C}$ ultimately passed through the grazers at PE, mostly the smaller protozoa and meiofauna (Figs. 9C \& 10C). This transfer of bacterial N-tracer to the grazers provided an efficient link for recycled nitrogen with small grazers that was not present for carbon. The linkage between bacteria and grazer populations was weaker at SMB.

The differences in nitrogen content of food suggests that there is greater diversity in the way POM is oxidized within a food web consisting of both a microbial and large grazers component than in the separate food web components. The low C production efficiencies of anaerobic microbiota allows them to meet their nitrogen requirements while feeding on resources with a high $\mathrm{C}: \mathrm{N}$ ratio (Table 4). The $\mathrm{CO}_{2}$ release associated with low $\mathrm{C}$ production efficiencies causes nitrogen to be conserved relative to carbon. Aerobic grazer organisms with higher production efficiencies require more nitrogen in their diet in our analysis. Our food web analysis suggests that microbial and faunal specialize in consuming different components of the available POM. Lee (1992) noted that a higher diversity of digestive mechanisms results in more complete oxidation of organic matter. If specialization results in more complete use of a resource, the diverse digestive mechanisms implied by the presence of both microbial and larger faunal organisms would result in more complete oxidation of available POM. Our tracer analyses suggest that infaunal feeding on bacteria (especially by protozoa) turns over the bacterial biomass rapidly and that release of DOM by the grazers provides much of bacterial nutrition. The major release of nutrients $(\mathrm{N})$ originating in bacteria is not released through a benthic microbial loop as suggested by Lee (1992) but is instead directly from bacterial release of ammonia (Table 2).

Reported assimilation efficiencies for infaunal grazers range from 5 to $20 \%$ (e.g. Cammen 1989). Unfortunately, neither gravimetric nor tracer methods can measure low assimilation efficiencies accurately, although assimilations between 0 and $5 \%$ have been reported (Lopez et al. 1989). Although our calculated food webs were designed to provide the type of substrate needed to support each trophic group, they were not very efficient. The low production efficiencies calculated from the food web suggest that the benthic organism retained little of the available energy (Table 4 ). We have not imposed a lower bound on carbon assimilation efficiency for grazers. Our method does not assess assimilation by an organism during a single pass of material through the gut but only the cumulative impact of the organism on the substrates entering the benthic sediments. 
Table 4. Carbon consumption and release by the anaerobic and bacteria and grazers. Production and respiration efficiencies are calculated. Flows in $\mu \mathrm{mol} \mathrm{C} \mathrm{m}^{-2} \mathrm{~d}^{-1}$

\begin{tabular}{|c|c|c|c|c|c|c|}
\hline & \multicolumn{3}{|c|}{ Patton Escarpment } & \multicolumn{3}{|c|}{ Santa Monica Basin } \\
\hline & Bact. total & Grazer total & Total & Bact. total & Grazer total & Total \\
\hline$\sum$ inputs $(C)$ & 547 & 1093 & 1639 & 1777 & 1934 & 3711 \\
\hline$\sum$ respiration $(R)$ & 493 & 645 & 1138 & 1693 & 1012 & 2704 \\
\hline$\sum$ detritus $(F)$ & 0 & 123 & 123 & 0 & 193 & 193 \\
\hline$\sum \mathrm{DOC}(U)$ & 4 & 213 & 216 & 2 & 566 & 567 \\
\hline$P=C-R-F-U$ & 50 & 112 & 162 & 83 & 163 & 246 \\
\hline Respiration efficiency $\left(R / \sum\right.$ inputs $\left.\times 100\right)$ & 90 & 59 & 69 & 95 & 52 & 73 \\
\hline Gross production efficiency $(\mathrm{P} / \Sigma$ inputs $\times 100)$ & 9 & 10 & 10 & 5 & 8 & 7 \\
\hline
\end{tabular}

The total oxygen consumption and the carbon sedimentation rates include the feeding and respiration needs of organisms suspension-feeding from the water column. Such organisms would be classified as macrofauna in our schema and their metabolic rates included in the flows to the macrofauna. The low macrofaunal respiration rates relative to those for other grazer groups suggest that filter feeding is a small part of the metabolic activity in the benthos. The small fraction for macrofauna ( $12 \%$ of the total $\mathrm{CO}_{2}$ release) in our analysis is similar to the $20 \%$ of the $P O C$ respiration that has been attributed to macrofauna in microcosm studies of oxygen-rich sediments (Billen 1978, Kristensen 1985, Kristensen \& Blackburn 1987). Survey data of deep benthic communities tend to corroborate the relatively small role of suspension feeders (Levinton 1989).

\section{Sulfur and nitrogen cycling}

The relative importance of sulfate reduction and denitrification is enhanced as rates of community metabolism increase (Canfield 1991b, Yoon \& Benner 1992). Near-shore benthos tends to have higher anaerobic carbon oxidation rates because higher sedimentation rates can overwhelm available $\mathrm{O}_{2}$ supply (Jørgensen 1982). At SMB, a thin oxygenated layer results from this high community metabolism and small $\mathrm{O}_{2}$ flux from the water column. Denitrification rates are generally less than those for sulfate reduction in near-shore sediments even though they are energetically more feasible (Jørgensen 1989). Denitrification is associated with the oxic/anoxic interface (Kristensen \& Blackburn 1987); sulfate reduction occurs throughout the anaerobic regions and is generally the terminal phase of organic material decomposition (Canfield 1991a, b). However, 33 and $25 \%$ of the carbon oxidation at SMB was by denitrification and sulfate reduction. Higher denitrification rates relative to those for sulfate reduction may result from a high nitrate supply in overlying waters and an abundance of labile detrital material near the shallow oxic/anoxic sediment interface. Yoon \& Benner (1992) measured similar denitrification rates in estuaries in Texas (USA) ( 4 to $71 \mathrm{vs} 45 \mu \mathrm{mol} \mathrm{m}{ }^{-2} \mathrm{~d}^{-1}$ for SMB). They estimated that denitrifying bacteria oxidized between 40 and $179 \%$ of the amount that aerobic organisms did. Denitrifying bacteria oxidized relatively more of the carbon at SMB because of the lower oxygen consumption rate there. Although the role of denitrification in carbon mineralization has not been extensively studied (Yoon \& Benner 1992), these results suggest its importance may rival sulfate reduction in some coastal sediment environments.

The deeper ocean benthos at PE has a lower community metabolism rate and a thicker oxygen-containing layer. A greater fraction of sedimenting material is typically oxidized in such a thick zone before it moves into the anoxic zone than in a region with a shallower oxygen-rich layer (Jørgensen 1983, Canfield 1989, $1991 \mathrm{~b})$. Sulfate reduction was the dominant anaerobic process in the $\mathrm{PE}$ sediments, although the ratio of $\mathrm{O}_{2}$ $/ \mathrm{SO}_{4}{ }^{2-}$ reduction rates was 36 there but 1 at $\mathrm{SMB}$. The ratio at $\mathrm{PE}$ is intermediate between typical coastal values ( 1 to 7 ) and deep-sea values ( $\geq 100$ ) (Jørgensen 1983, Canfield 1989). Although we accounted for metabolic efficiency for $\mathrm{SO}_{4}{ }^{2-}$ usage in a somewhat arbitrary way (see 'Methods'), the rate of sulfate reduction calculated by the inverse method $\left(34 \mu \mathrm{mol} \mathrm{m}^{-1} \mathrm{~d}^{-1}\right)$ was close to values reported at other locations in the region ( $27 \mu \mathrm{mol} \mathrm{m} \mathrm{m}^{-1} \mathrm{~d}^{-1}$ ) (Canfield 1991b).

Reimers \& Smith (1986) have suggested that much of the regenerated nitrogen at PE is used in nitrification. Such sedimentary consumption is consistent with our result that denitrification oxidized $43 \%$ to total anaerobic carbon oxidation and was a sink for much of the regenerated ammonia (Fig. 7). Thus, nitrogen cycling is very dynamic in the shelf/slope sediments off southern California.

\section{Limitations of data and inverse formulations}

Nothing describes any system better than direct measurements of all its relevant properties. Unfortunately, we work with incomplete descriptions, particularly with deep-sea ecosystems. In the absence of 
desired measurements, the inverse approach offers a way to estimate unknown system properties using a variety of information. As with any estimate, the accuracy of results varies. Among the factors that can affect the validity of an analysis are erroneous data, insufficient descriptive data, faulty system description, and an inappropriate minimization function.

No set of numbers is completely accurate. In some cases, there are methodological limits or uncertainties. In others, measurements are taken over too short a period of time to adequately represent the system. For example, Smith et al. (1992) concluded that carbon fluxes calculated from sediment trap accumulations at $\mathrm{PE}$ represented only 3 to $40 \%$ of the sediment oxygen demand. They argued that the difference resulted from episodic detrital input that was not sampled and from conversion of POC to DOC in the sediment traps. For this particular case, we did not use the reported sediment trap fluxes but did use the average sediment respiration values. The reported sediment trap fluxes accounted for only $21 \%$ of the carbon flux to the sediments that we inferred from the calculations. We could incorporate change in our analysis if there were more information about temporal variations in flows and biomass. The results shown here represent average system flows.

The sensitivity analysis (Table 3) showed the effect that small errors in data values would have on analysis results for the entire system. Changes in supply rates for oxygen, nitrate, and the carbon burial rate that are small relative to their original values had a minuscule effect on the fraction of community carbon dioxide and ammonia formation by the grazers; small changes in total $\mathrm{CO}_{2}$ fluxes caused small changes in carbon dioxide ratio at $\mathrm{PE}$, but not in the equivalent ammonia rates. The $\mathrm{O}_{2}$ flux had more of an effect on the rate of ammonia formation. The values that we chose to represent the $\mathrm{C}: \mathrm{N}$ of organisms had an equally small effect on the grazer fraction of community metabolism. The nutritional contents of organisms, as described by their $\mathrm{C}: \mathrm{N}$ values, are important parameters which we have had to assume but which would be important to know more accurately.

The maximum and minimum biomass production rates possible at given rates of oxidant respiration are important, poorly know values. The biomass production rates calculated in our analyses for the heterotrophic bacteria were the minimum allowed by the constraints we imposed. We set the maximum biomass production rates to be consistent with growth rates reported by Deming and Yager (1992), in deep-sea sediments. If these values are too large, our estimates of bacterial biomass production rates are too large. More laboratory experiments could determine whether this is really the case.
Eldridge \& Jackson (1992) examined the effects of modifying the benthic food web structure on the flows resulting from this inverse analysis procedure. They found that allowing grazers at $\mathrm{SMB}$ to consume only bacterial biomass, no detritus, increased the activity of the aerobic bacteria at the expense of the grazers. As a result, the assumption about the allowable interactions in the food web can have large effects on the results.

Insufficient data and faulty system description are closely related problems. It does no good to use a very elaborate set of compartments if there is not enough information to constrain the flows. Our description of the benthic ecosystem is as a fairly simple trophic box model in which the equations describing the system are linear and the system is at steady state. Much of the linearity results from the need to balance mass. The inverse approach can be expanded to include a timevarying system of considerably more complexity having nonlinear constraints (e.g. Jackson \& Eldridge 1992). However, such a description would require more information, particularly about changes in compartment sizes. This problem of needing more information before expanding the complexity of the description applies to other benthic properties as well.

We followed Reimers \& Smith's (1986) usage at Patton Escarpment of Snider et al.'s (1984) relative species composition of deep-sea benthos, but were concerned that it might not be appropriate for the mesotrophic benthic environment. However, sensitivity analyses show that changes in biomass data had little effect on results.

The redox state of the system could be expanded to include organic compounds with redox states other than 0 . While the carbon in organic matter is frequently assumed to have a redox state of 0 (e.g. Stumm \& Morgan 1981, Jahnke 1990), having only one form of reduced carbon does not allow anaerobic metabolism involving fermentation reactions, in which there is simultaneous oxidation and reduction of different carbon fractions rather than reduction of oxygen or nitrate. Sulfate- and iron-reducing bacteria often work with fermentation bacteria to oxidize organic matter (Widdel 1988, Lovley \& Phillips 1989). Sulfate-reducing bacteria always oxidize low molecular-weight organic carbon compounds; nearly all of these are produced by the fermentation of carbohydrates, proteins and other components of dead biomass (e.g. Widdel 1988). Our simplified analysis allowed sulfate- and iron-reducing bacteria to oxidize all substrates, whether the results of fermentation or not. Including flows of $\mathrm{C}$ with different redox states would involve knowing the range of efficiencies for all reactions involving each state. This is beyond our present state of knowledge.

There may be other ways to enforce oxidant preferences than our admittedly arbitrary use of scaling constants. Widdel (1988) suggested that Monod-type 
rate relationships between oxidant concentrations and their reaction rates can be used. In order to do so, one would need to have better spatial resolution in the system description to include the different oxidant conditions beneath the sedimentary surface.

Profiles of dissolved oxidant concentrations in the sediment can be used to infer diffusive flux rates as well as provide concentrations. Their incorporation into system descriptions using relationships between oxidant concentration and consumption, as proposed by Widdel (1988) would allow a much finer description of the chemical environment.

Flows which the analysis shows to be zero may, in reality, not be. However, until there is evidence to the contrary there is no reason to assume that they are nonzero. For example, we saw virtually no DOM leakage by bacteria. Given that heterotrophica bacteria live by consuming organic matter, there is no reason to invoke DOM leakage in the absence of information to justify it.

Our optimization approach has a bias that reduces recycling and emphasizes metabolic processes such as respiration and nitrogen regeneration because it minimizes the sum of the squares of the flows and maximizes respiration flows leaving the system. Such minimization must be consistent with the various constraints, including the carbon-nitrogen constraints that link the different elemental flows (Figs. $3 \& 4$ ). The minimum set of flows does provide, in some ways, the 'simplest' estimate of the benthic foodweb consistent with the known data. Whether this is the 'best' estimate is related to the question of whether the flows are the best things to minimize. Without further experience, we cannot unequivocally state that they are. Similarly, without more experience with benthic ecosystems, we cannot determine what is the appropriate detail level for the system description.

The benthos is probably unique among ecosystems in the extent to which complex chemical processes interact with as many different groups of biological organisms. The inverse formulation that we have presented offers a means to integrate chemical and biological information to make inferences about material flows in a benthic system. Hopefully, the results will stimulate field experiments to test the conclusions and motivate laboratory experiments to measure the various physiological efficiencies of benthic organisms. More detailed studies of processes in benthic systems could provide more and better information to initialize the analysis. Furthermore, they would allow a more elaborate description of the benthic food web in the inverse analysis. As such, the approach and results that we have presented should be seen as a first effort which integrates many approaches to the study of benthic communities.

Acknowledgements. This work was supported by Office of Naval Research Contract N00014 87-K0005 and U.S. Department of Energy grant DE-FG05-85-ER60341. J. D. Haney helped with graphics routines. We thank C. E. Reimers, G. Rowe and R. Jahnke for helpful discussions.

\section{Appendix 1}

Elemental flows used in model. $C, N, O, F e, S$ : carbon, nitrogen, oxygen, tron, and sulfur flows; $M$ : combination $C$ and $N$ flows (symbols in parenthesis are for the $\mathrm{N}$ cases). Units are $\mu \mathrm{M} \mathrm{m}^{-2} \mathrm{~d}^{-1}$ The first subscript indicates the source of the flow, the second is the sink. Superscript indicates organism that mediated the flow. Subscript abbreviations are wc: water column; o2: molecular oxygen; s2: sulfide; s3: sulfate; fes: ferrous sulfide; f2: ferrous iron: f3: ferric iron; n5: nitnte; n6: nitrate; $\mathrm{nh}$ : ammonia; $\mathrm{n}$ : nitrogen; $\mathrm{co}: \mathrm{CO}_{3}$; do: dissolved organic matter; de: detritus; se: sedimentation; bu: burial; b1: ammonia using nitrifying bactena $(1\}_{;}$b2: nitrite using nitrifying bacteria (2); b3: ferrous-utilizing bacteria; b4: sulfide-utilizing bacteria; bS: oxygen-utilizing heterotrophic bacteria; b6: nitrate-utilizing heterotrophic bacteria; b7: sulfate-utilizing heterotrophic bacteria; b8: ferric-utilizing heterotrophic bacteria; $g 1$ : anoxic-tolerant microfauna; g2: oxygen-requiring microfauna; g3: meiofauna; g4: macrofauna

\begin{tabular}{|c|c|c|c|c|c|}
\hline \multirow[t]{2}{*}{ Symbol } & \multirow[t]{2}{*}{ Description } & \multicolumn{2}{|c|}{$\mathrm{SMB}$} & \multicolumn{2}{|c|}{$\mathrm{PE}$} \\
\hline & & C/other & $\mathrm{N}$ & C/other & $N$ \\
\hline$O_{w c, 02}$ & $\mathrm{O}_{2}$ from water column into sediments & 360.0 & - & 1200 & - \\
\hline $\mathrm{Obt}_{6200}$ & $\mathrm{O}_{2}$ to $\mathrm{CO}_{2}$ by nitnfying bacteria (1) & 0 & - & 1.1 & - \\
\hline $\mathrm{O}^{\mathrm{b} 2} \mathrm{2} 2 \mathrm{200}$ & $\mathrm{O}_{2}$ to $\mathrm{CO}_{2}$ by nitrnying bacteria $(2)$ & 0 & - & 0.4 & - \\
\hline $\mathrm{O}^{\mathrm{b} 3} \mathrm{02.00}$ & $\mathrm{O}_{2}$ to $\mathrm{CO}_{2}$ by $\mathrm{Fe}^{2+}$ oxidizing bacteria & 0 & - & 0.4 & - \\
\hline $\mathrm{O}^{\mathrm{b} 4} \mathrm{D2, \textrm {CO }}$ & $\mathrm{O}_{2}$ to $\mathrm{CO}_{2}$ by $\mathrm{S}^{2-}$ oxidizing bacteria & 0 & - & 3.4 & - \\
\hline $\mathrm{O}^{\mathrm{b5}}{ }_{\mathrm{o} 2, \mathrm{co}}$ & $\mathrm{O}_{2}$ to $\mathrm{CO}_{2}$ by heterotrophic bactena & 13.9 & $=$ & 396.4 & - \\
\hline 0920200 & $\mathrm{O}_{2}$ to $\mathrm{CO}_{2}$ by microfauna & 90.8 & - & 258.9 & - \\
\hline $\mathrm{Og}^{3} \mathrm{azco}$ & $\mathrm{O}_{2}$ to $\mathrm{CO}_{2}$ by melofauna & 119.4 & - & 250.3 & - \\
\hline $09402 . c 0$ & $\mathrm{O}_{2}$ to $\mathrm{CO}_{2}$ by macrofauna & 135.9 & - & 135.3 & - \\
\hline $003_{02.05}$ & $\mathrm{O}_{2}$ to $\mathrm{NO}_{2}$ by nitrfying bacteria & 0 & - & 57.8 & - \\
\hline $\mathrm{O}^{\mathrm{b} 2} \mathrm{o}_{02, \mathrm{n} 6}$ & $\mathrm{O}_{2}$ to $\mathrm{NO}_{3}$ by nitrifying bacteria & 0 & - & 19.3 & - \\
\hline $\mathrm{O}^{\mathrm{b}} \mathrm{3}_{02.13}$ & $\mathrm{O}_{2}$ to $\mathrm{Fe}^{3+}$ by ferrous oxidizing bacteria & 0 & - & 9.4 & - \\
\hline $\mathrm{O}^{\mathrm{b4}} \mathrm{s2, \textrm {s } 3}$ & $\mathrm{O}_{2}$ to $\mathrm{S}_{4}{ }^{2-}$ by sulfide oxidizing bacteria & 0 & - & 67.3 & - \\
\hline$S_{\text {wess }}$ & $\mathrm{SO}_{4}{ }^{2-}$ from water column into sediments & 400.0 & - & 0 & - \\
\hline$S_{\mathrm{s} 3,52}$ & $\mathrm{SO}_{4}^{2-}$ to $\mathrm{S}^{2-}$ by sulfate-reducing bacteria & 400.0 & - & 33.7 & - \\
\hline$S^{04} \times 2.53$ & $\mathrm{~S}^{2-}$ to $\mathrm{SO}_{4}{ }^{2+}$ by sulfide-oxidizing bactera & 0 & - & 33.7 & - \\
\hline$S_{s 2, t e s}$ & $\mathrm{~S}^{2-}$ to $\mathrm{FeS}$ & 400.0 & - & 0 & - \\
\hline$F e_{\text {se }} / 3$ & Sedimentation uron flow to $\mathrm{Fe}^{3+}$ & 400.0 & - & 0 & - \\
\hline$F e^{b 8}+13,12$ & $\mathrm{Fe}^{3 *}$ to $\mathrm{Fe}^{2+}$ by terric-reducing bacteria & 400.0 & - & 37.8 & - \\
\hline $\mathrm{Feb}_{12,93}$ & $\mathrm{Fe}^{2 *}$ to $\mathrm{Fe}^{3 *}$ by ferrous-oxidizing bacteria & 0 & - & 37.8 & - \\
\hline $\mathrm{Fe}_{12 \text { ies }}$ & $\mathrm{Fe}^{2+}$ flow to FeS & 400.0 & - & 0 & - \\
\hline
\end{tabular}




\begin{tabular}{|c|c|c|c|c|c|}
\hline \multirow[t]{2}{*}{ Symbol } & Description & & & & \\
\hline & & C/other & $\mathrm{N}$ & C/other & $\mathrm{N}$ \\
\hline$N^{b 1}$ nh.n5 & $\mathrm{NH}_{3}$ to $\mathrm{NO}_{2}{ }^{-}$by nitrifying bacteria & - & 1100.0 & - & 38.5 \\
\hline$N^{b 2}{ }_{n 5}$ int & $\mathrm{NO}_{2}$ to $\mathrm{NO}_{3}^{-}$by nitrifying bacteria & - & 0 & - & 38.5 \\
\hline$N b 6$ n6.n2 & $\mathrm{NO}_{3}^{-}$to $\mathrm{N}_{2}$ by denitrifying bacteria & - & 1100.0 & - & 46.9 \\
\hline$N_{\mathrm{wc}, \mathrm{n} 6}$ & $\mathrm{NO}_{3}$ from water column into sediments & - & 1100.0 & - & 8.3 \\
\hline$M_{\mathrm{Co}[\mathrm{nh}, \mathrm{b} 1}$ & $\mathrm{CO}_{2}\left(\mathrm{NH}_{3}\right)$ to nitrifying bacteria (1) & 0 & 0 & 1.1 & 0.4 \\
\hline$M_{\text {colnh].b2. }}$ & $\mathrm{CO}_{2}\left(\mathrm{NH}_{3}\right)$ to nitrifying bacteria (2) & 0 & 0 & 0.4 & 0 \\
\hline$M_{C o(n h) \cdot b 3}$ & $\mathrm{CO}_{2}\left(\mathrm{NH}_{3}\right)$ to ferrous bacteria (1) & 4.0 & 1.3 & 0.4 & 0 \\
\hline$M_{c o(n h), b 4}$ & $\mathrm{CO}_{2}\left(\mathrm{NH}_{3}\right)$ to $\mathrm{S}^{2-}$ oxidizing bacteria & 0 & 0 & 3.4 & 0 \\
\hline$N_{\text {nh, bs }}$ & $\mathrm{NH}_{3}$ to heterotrophic aerobic bacteria & - & 0 & - & 0 \\
\hline$N_{\text {nh }} b_{5}$ & $\mathrm{NH}_{3}$ to denitrifying bacteria & - & 0 & - & 0 \\
\hline$N_{\text {nh, b }}$ & $\mathrm{NH}_{3}$ to sulfate-reducing bacteria & - & 0 & - & 0 \\
\hline$N_{\mathrm{nh}, \mathrm{b} 8}$ & $\mathrm{NH}_{3}$ to ferric-iron reducing bacteria & - & 0 & - & 0 \\
\hline$M_{\text {b1,coinhi }}$ & Nitrifying bacteria (1) to $\mathrm{CO}_{2}\left(\mathrm{NH}_{3}\right)$ & 0 & 0 & 1.1 & 0.4 \\
\hline$M_{\mathrm{b} 2, \mathrm{colnh})}$ & Nitrifying bacteria (2) to $\mathrm{CO}_{2}\left(\mathrm{NH}_{3}\right)$ & 0 & 0 & 0.4 & 0 \\
\hline$M_{\mathrm{b} 3, \mathrm{co}(\mathrm{nh}}$ & Ferrous-oxidizing bacteria to $\mathrm{CO}_{2}\left(\mathrm{NH}_{3}\right)$ & 4.0 & 1.3 & 0.4 & 0 \\
\hline$M_{\mathrm{b} 4, \mathrm{CO}(\mathrm{nh})}$ & Sulfide-oxidizing bacteria to $\mathrm{CO}_{2}\left(\mathrm{NH}_{3}\right)$ & 0 & 0 & 3.4 & 0 \\
\hline$M_{\mathrm{b}, \mathrm{co}(\mathrm{nh})}$ & Heterotrophic aerobic bacteria to $\mathrm{CO}_{2}\left(\mathrm{NH}_{3}\right)$ & 13.9 & 4.7 & 396.4 & 13.1 \\
\hline$M_{\mathrm{b} 6, \mathrm{co}(\mathrm{nh})}$ & Denitrifying bacteria to $\mathrm{CO}_{2}\left(\mathrm{NH}_{3}\right)$ & 914.8 & 43.3 & 39 & 9.6 \\
\hline$M_{\mathrm{b} 7, c o(n h)}$ & Sulfate-reducing bacteria to $\mathrm{CO}_{2}\left(\mathrm{NH}_{3}\right)$ & 659.8 & 53.7 & 45 & 13.9 \\
\hline$M_{\mathrm{b} 8, \text { colnh) }}$ & Ferric-reducing bacteria to $\mathrm{CO}_{2}\left(\mathrm{NH}_{3}\right)$ & 100.0 & 33.7 & 7.6 & 2.5 \\
\hline$M_{g 1, \text { co(nh) }}$ & Anaerobic microfauna to $\mathrm{CO}_{2}\left(\mathrm{NH}_{3}\right)$ & 665.5 & 51.2 & 0 & 18.7 \\
\hline$M_{\mathrm{g} 2, \mathrm{co}(\mathrm{nh})}$ & Aerobic microfauna to $\mathrm{CO}_{2}\left(\mathrm{NH}_{3}\right)$ & 90.8 & 30.6 & 258.9 & 19.9 \\
\hline$M_{\mathrm{g} 3, \operatorname{co}(\mathrm{nh})}$ & Meiofauna to $\mathrm{CO}_{2}\left(\mathrm{NH}_{3}\right)$ & 119.4 & 40.2 & 250.3 & 19.2 \\
\hline$M_{\mathrm{g} 4, \mathrm{co}(\mathrm{nh})}$ & Macrofauna to $\mathrm{CO}_{2}\left(\mathrm{NH}_{3}\right)$ & 135.9 & 45.8 & 135.3 & 19.3 \\
\hline$M_{\mathrm{b} 1, \mathrm{dc}(\mathrm{dn})}$ & Nitrifying bacteria (1) to DOC (DON) & 0 & 0 & 0 & 0 \\
\hline$M_{\mathrm{b} 2 \mathrm{dc}(\mathrm{dn})}$ & Nitrifying bacteria (2) to DOC (DON) & 0 & 0 & 0 & 0 \\
\hline$M_{\mathrm{b} 3, \mathrm{de}(\mathrm{dn})}$ & Ferrous-oxidizing bacteria to DOC (DON) & 0 & 0 & 0 & 0 \\
\hline$M_{\mathrm{b} 4 \text { deldn) }}$ & Sulfide-oxidizing bacteria to DOC (DON) & 0 & 0 & 0 & 0 \\
\hline$M_{\mathrm{bS}, \mathrm{d}(\mathrm{d}(\mathrm{n})}$ & Aerobic bacteria to DOC (DON) & 1.5 & 0 & 0 & 0 \\
\hline$M_{\text {b6,dcidn) }}$ & Denitrifying bacteria to DOC (DON) & 0 & 0 & 0 & 0 \\
\hline$M_{\mathrm{b} 7, \mathrm{dc}(\mathrm{d} n)}$ & Sulfate-reducing bacteria to DOC (DON) & 0 & 0 & 0 & 0 \\
\hline$M_{\mathrm{b} 8, \mathrm{dc} d \mathrm{dn})}$ & Ferric-reducing bacteria to DOC (DON) & 0 & 0 & 3.6 & 0 \\
\hline$M_{\text {gi,dcidn) }}$ & Anaerobic microfauna to DOC (DON) & 219.6 & 7.7 & 0 & 0 \\
\hline$M_{g 2, d c(d n)}$ & Aerobic microfauna to DOC (DON) & 90.8 & 22.2 & 85.4 & 0 \\
\hline$M_{\mathrm{g} 3, \mathrm{dc}(\mathrm{d} n\}}$ & Meiofauna to DOC (DON) & 119.4 & 22.7 & 82.6 & 16.5 \\
\hline$M_{\mathrm{g} 4, \mathrm{dc}(\mathrm{d} n)}$ & Macrofauna to DOC (DON) & 135.9 & 24.7 & 44.7 & 2.7 \\
\hline$M_{\mathrm{b} 1, \text { de }}$ & Nitrifying bacteria (1) to detritus & 0 & 0 & 0 & 0 \\
\hline$M_{\mathrm{b} 2 \mathrm{de}}$ & Nitrifying bacteria (2) to detritus & 0 & 0 & 0 & 0 \\
\hline$M_{\mathrm{b} 3 \text {,de }}$ & Ferrous-oxidizing bacteria to detritus & 0 & 0 & 0 & 0 \\
\hline$M_{\mathrm{b} 4 \mathrm{de}}$ & Sulfide-oxidizing bacteria to detritus & 0 & 0 & 0 & 0 \\
\hline$M_{\mathrm{bS} \text {.de }}$ & Heterotrophic aerobic bacteria to detritus & 0 & 0 & 0 & 0 \\
\hline$M_{\mathrm{bG}, \mathrm{de}}$ & Denitrifying bacteria to detritus & 0 & 0 & 0 & 0 \\
\hline$M_{\mathrm{b} 7, \mathrm{de}}$ & Sulfate-reducing bacteria to detritus & 0 & 0 & 0 & 0 \\
\hline$M_{\mathrm{b} 8 \text {,de }}$ & Ferric-reducing bacteria to detritus & 0 & 0 & 0 & 0 \\
\hline$M_{\mathrm{gl} 1 \mathrm{de}}$ & Anaerobic microfauna to detritus & 110.6 & 22.1 & 18.5 & 3.7 \\
\hline$M_{\mathrm{g} 2 \text {,de }}$ & Aerobic microfauna to detritus & 22.7 & 4.5 & 43 & 8.6 \\
\hline$M_{\mathrm{g} 3 \text {, de }}^{\text {gat }}$ & Meiofauna to detritus & 29.8 & 6 & 41.6 & 8.3 \\
\hline$M_{g 4, \text { de }}$ & Macrofauna to detritus & 30.2 & 6 & 20 & 4 \\
\hline$M_{\mathrm{do}, \mathrm{b} 5}$ & DOC (DON) to heterotrophic aerobic bacteria & 15.4 & 4.7 & 440.5 & 21.9 \\
\hline$M_{\mathrm{do}, \mathrm{b} 6}$ & DOC (DON) to denitrifying bacteria & 962.9 & 52.9 & 41 & 10 \\
\hline$M_{\mathrm{do}, \mathrm{b}}$ & DOC (DON) to sulfate-reducing bacteria & 694.5 & 59.6 & 47.3 & 14.3 \\
\hline$M_{\mathrm{do}, \mathrm{b} 8}$ & DOC (DON) to ferric-reducing bacteria & 100.0 & 33.7 & 12.4 & 2.8 \\
\hline$M_{\mathrm{b} 1, \mathrm{~g} 2}$ & Nitrifying bacteria to aerobic microfauna & 0 & 0 & 0 & 0 \\
\hline$M_{\mathrm{b} 2, \mathrm{~g}^{2}}$ & Nitrifying bacteria to aerobic microfauna & 0 & 0 & 0 & 0 \\
\hline$M_{\mathrm{b} 3 . \mathrm{g} 2}$ & Ferrous-oxidizing bacteria to aerobic microfauna & 0 & 0 & 0 & 0 \\
\hline$M_{\mathrm{b} 4 \mathrm{~g} 2}$ & Sulfide-oxidizing bacteria to aerobic microfauna & 0 & 0 & 0 & 0 \\
\hline$M_{\mathrm{b} 5, \mathrm{~g}^{2}}$ & Heterotrophic bacteria to aerobic microfauna & 0 & 0 & 27.8 & 5.6 \\
\hline$M_{\mathrm{bG}, \mathrm{g} 1}$ & Denitrifying bacteria to anaerobic microfauna & 48.1 & 9.6 & 0 & 0 \\
\hline Mbr.g1 & Sulfate-oxidizing bacteria to anaerobic microfauna & 34.7 & 5.9 & 0 & 0 \\
\hline$M_{\mathrm{b} 8 . \mathrm{gl}}$ & Ferrous-oxidizing bacteria to anaerobic microfauna & 0 & 0 & 0 & 0 \\
\hline$M_{\mathrm{b} 1 . \mathrm{g} 3}$ & Nitrifying bacteria to meiofauna & 0 & 0 & 0 & 0 \\
\hline$M_{\mathrm{b} 2, \mathrm{~g} 3}$ & Nitrifying bacteria to meiofauna & 0 & 0 & 0 & 0 \\
\hline$M_{\mathrm{b} 3, \mathrm{~g} 3}$ & Ferrous-oxidizing bacteria to meiofauna & 0 & 0 & 0 & 0 \\
\hline$M_{\mathrm{ba}, \mathrm{g} 3}$ & Sulfide-oxidizing bacteria to meiofauna & 0 & 0 & 0 & 0 \\
\hline$M_{\mathrm{bs}, \mathrm{g} 3}$ & Heterotrophic bacteria to meiofauna & 0 & 0 & 16.2 & 3.2 \\
\hline$M_{\mathrm{b} 6, \mathrm{~g} 3}$ & Denitrifying bacteria to meiofauna & 0 & 0 & 2.1 & 0.4 \\
\hline$M_{\mathrm{b} 7 . \mathrm{g} 3}$ & Sulfate-oxidizing bacteria to meiofauna & 0 & 0 & 2.4 & 0.4 \\
\hline$M_{\mathrm{b} 8, \mathrm{~g} 3}$ & Ferrous-oxidizing bacteria to meiofauna & 0 & 0 & 1.2 & 0.2 \\
\hline$M_{\mathrm{b} 1, \mathrm{ga}}$ & Nitrifying bacteria (1) to macrofauna & 0 & 0 & 0 & 0 \\
\hline$M_{\mathrm{b} 2, \mathrm{ga}^{4}}$ & Nitrifying bacteria (2) to macrofauna & 0 & 0 & 0 & 0 \\
\hline$M_{\mathrm{b} 3, \mathrm{~g} 4}$ & Ferrous-oxidizing bacteria to macrofauna & 0 & 0 & 0 & 0 \\
\hline$M_{\mathrm{bA}, \mathrm{gA}}$ & Sulfide-oxidizing bacteria to macrofauna & 0 & 0 & 0 & 0 \\
\hline$M_{\mathrm{bs}, \mathrm{g}^{4}}$ & Heterotrophic bacteria to macrofauna & 0 & 0 & 0 & 0 \\
\hline$M_{\mathrm{b} 6.9^{4}}$ & Denitrifying bacteria to macrofauna & 0 & 0 & 0 & 0 \\
\hline$M_{\mathrm{b} 7.94}$ & Sulfate-oxidizing bacteria to macrofauna & 0 & 0 & 0 & 0 \\
\hline$M_{\mathrm{b} 8 \mathrm{gd}}$ & Ferrous-oxidizing bacteria to macrofauna & 0 & 0 & 0 & 0 \\
\hline$M_{\mathrm{g} 1.93}$ & Anaerobic microfauna to meiofauna & 51.1 & 10.2 & 27.7 & 5.5 \\
\hline$M_{\mathrm{g} 1, \mathrm{gd}}$ & Anaerobic microfauna to macrofauna & 59.5 & 11.9 & 0 & 0 \\
\hline$M_{\mathrm{g} 2, \mathrm{~g} 3}$ & Aerobic microfauna to meiofauna & 0 & 0 & 43 & 8.6 \\
\hline$M_{g 2, g 4}$ & Aerobic microfauna to macrofauna & 22.7 & 4.5 & 0 & 0 \\
\hline$M_{\mathrm{g} 3, \mathrm{~g} 4}$ & Meiofauna to macrofauna & 29.8 & 6.0 & 41.6 & 8.3 \\
\hline$M_{\text {se,de }}$ & Sedimentation to detritus & 3670.0 & 360.0 & 1242.5 & 126.1 \\
\hline$M_{\text {de,g1 }}$ & Detritus to anaerobic microfauna & 1023.4 & 87.6 & 46.2 & 28.0 \\
\hline$M_{\mathrm{de}, \mathrm{g} 2}$ & Detritus to aerobic microfauna & 227.0 & 61.9 & 402.6 & 31.6 \\
\hline$M_{\text {de.g3 }}$ & Detritus to meiofauna & 247.3 & 64.6 & 323.4 & 33.9 \\
\hline$M_{\text {de }, 94}$ & Detritus to macrofauna & 190.1 & 54.1 & 158.4 & 17.7 \\
\hline$M_{\text {coinhi,we }}$ & $\mathrm{CO}_{2}\left(\mathrm{NH}_{3}\right)$ exchange with the water column & 2700.0 & 303.0 & 1132.0 & 77.8 \\
\hline$M_{\text {de.do }}$ & Detritus to DOC (DON) & 360.0 & 73.5 & 290.2 & 29.8 \\
\hline$M_{\text {de, bu }}$ & Detritus to permanent burial & 970.0 & 57 & 110.0 & 9.7 \\
\hline
\end{tabular}


Equations describing the benthic food web. Data equations and constraints that are dufferent at each site are presented separately. $C_{b l-8}$ : bacterial $\mathrm{C}$ biomass; $C_{g 1-2}$ : microfaunal $\mathrm{C}$ biomass; $C_{\mathrm{g} 3}$ : meiofaunal $\mathrm{C}$ biomass; $C_{\mathrm{g}}$ : macrofauna $\mathrm{C}$ biomass. $R_{x}: \mathrm{N}: \mathrm{C}$ ratio $(=0.20$ for all organisms with the exception of the sulfate reducing bacteria b7 which has a ratio of 0.17 ). $A_{\text {buc }}=0.365 . A_{\text {pro }}=0.005, A_{\text {mel }}=0.001$, and $A_{\text {mac }}=6.0 \times 10^{-4}$ : respiration coefficients derived from the size spectrum of organisms (G. T. Rowe pers. comm.) and a metabolism function (Eq. 27; Platt et al. 1984) for bacteria, microfauna, meiofauna and macrofauna: $T_{1}=\exp (0.0692$ temperature): temperature adjustment for metabolic relationships (Vézina \& Platt 1988). $C_{\mathrm{bac}}=0.236, C_{\mathrm{mic}}=12.42, C_{\mathrm{mel}}=2.4, C_{\mathrm{mac}}=2.4 \mathrm{mmol} \mathrm{C} \mathrm{m}{ }^{2}$ : biomass of bacteria, meiofauna, and macrofauna at Patton Escarpment calculated from abundance data (Reimers 1987) and converted (Rowe 1983) to biomass. Macrofauna abundance at Santa Monica basin $\left(C_{\operatorname{mac}}=15 \mathrm{mmol} \mathrm{C} \mathrm{m}^{-2}\right)$ is from Thompson et al (1990). $I_{\mathrm{mac}}=0074 \mathrm{~d}^{-1}$ : maximum specific ingestion, derived similarly to respiration (Cammen $1980 \mathrm{~b}$ ). $R_{\mathrm{pum}}=1 / 11.3:$ mean $\mathrm{N}: \mathrm{C}$ ratio of surface sediments analysis on 5 cruises (Smith 1987) at stations near Patton Escarpment; $R_{\text {porm }}=1 / 17$ : minimum N:C ratio of buried POM at Santa Monica Basin (Sweeny et al. 1980); $R_{\text {sed }}=1 / 9.8: \mathrm{N}: \mathrm{C}$ ratio of sedimenting material at Patton Escarpment $\left(S \mathrm{Smith}\right.$ et al. 1983); $R_{\mathrm{sed}}=1 / 10.2$ : $\mathrm{N}: \mathrm{C}$ ratio of sedimenting material at Santa Monica Basin (Jackson 1989). Temperature: $1.7^{\circ} \mathrm{C}$ at PE (Smith 1983) and $5^{\circ} \mathrm{C}$ at SMB (Jahnke 1990 ). Burial rate at PE was based on an interpolation of sedimentation rates and density (G. A. Jackson et al. unpubl.). Nitrate, ferric iron, and sulfate reduction are divided by 3, 9 and 27 respectively (see text). Sources are 1: Fenchel \& Blackburn (1979); 2: Nagata (1986); 3: Finlay \& Uhlig (1981); 4: Fenchel (1987); 5: Kemp (1987); 6: Zehnder \& Stumm (1988); 7: Jahnke (1990); 8: Thompson et al. (1990); 9: Sweeny et al. (1980); 10: Reimers $(1987)$; 11: Reimers \& Smith (1986); 12: Smith et al. (1983); 13: Moore et al. (1980); 14: Wenkam (1976); 15: Smith (1987); 16: Snider et al. (1984); 17: Vézina \& Platt (1988); 18: Stouthamer (1988); 19: Lovley \& Phillips (1989); 20: Cammen (1980a); 21: Cammen (1980b); 22: G. T. Rowe (pers. comm.) 23: Platt et al. (1984); 24: R. A. Jahnke \& G. A. Jackson (unpubl.)

\begin{tabular}{|c|c|c|c|}
\hline Description & Equation & & Source \\
\hline \multicolumn{4}{|l|}{ Equations describing mass balance } \\
\hline \multicolumn{4}{|l|}{ Inorganic chemical species } \\
\hline Oxygen & 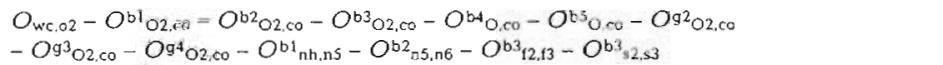 & $=0$ & - \\
\hline Sulfide & 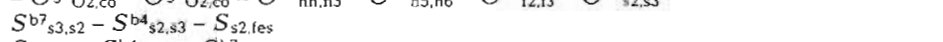 & $=0$ & - \\
\hline Sulfate & $S_{w_{1}, 33}+S^{b 4}{ }_{s 2,3}-S^{b 7_{s} 3.52}$ & $=0$ & - \\
\hline Ferrous iron & 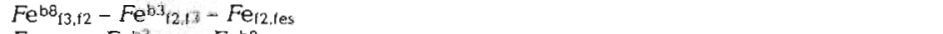 & $=0$ & - \\
\hline Ferric iron & 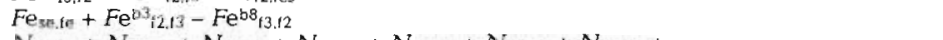 & $=0$ & - \\
\hline N-ammonia & $\begin{array}{l}N_{\mathrm{b} 1, \mathrm{nh}}+N_{\mathrm{b} 2, \mathrm{nh}}+N_{\mathrm{b}, \mathrm{nh}}+N_{\mathrm{bH}, \mathrm{nh}}+N_{\mathrm{b} 5, \mathrm{nh}}+N_{\mathrm{b} 6, \mathrm{nh}}+N_{\mathrm{b} 7, \mathrm{nh}}+ \\
N_{\mathrm{b} g, \mathrm{nh}}+N_{\mathrm{g} 1, \mathrm{nh}}+N_{\mathrm{g} 2, \mathrm{nh}}+N_{\mathrm{g} 3, \mathrm{nh}}+N_{\mathrm{g} 4, \mathrm{nh}}-N_{\mathrm{bh}, \mathrm{bl}}-N_{\mathrm{nh}, \mathrm{b} 2}-\end{array}$ & & \\
\hline & $N_{n h, b 3}-N_{n h, b 4}-N_{n h, b 5}-N_{n h, b 6}-N_{n h, b 7}-N_{n h, b 8}-N_{n h, a 15}-N_{n h, w c}$ & $=0$ & - \\
\hline N-nitrite & $N{ }^{b}{ }_{n h, n 5}^{1}-N{ }^{b}{ }_{n}{ }_{n, n 6}$ & $=0$ & - \\
\hline $\mathrm{N}$-nitrate & $N_{w c . n 6}+N^{b 2} 2_{n, n 6}-N^{b 6} b_{n, n 2}$ & $=0$ & - \\
\hline N-DOM & 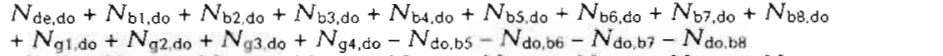 & $=0$ & - \\
\hline N-detritus & 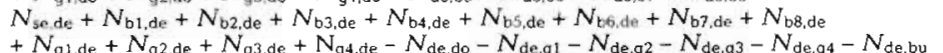 & $=0$ & - \\
\hline $\mathrm{C}-\mathrm{CO}_{2}$ & 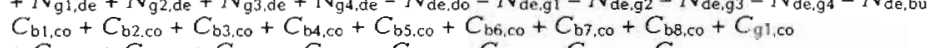 & $=0$ & - \\
\hline C-DOC & $\begin{array}{l}+C_{\mathrm{g} 2, \mathrm{co}}+C_{\mathrm{g} 3, \mathrm{co}}+C_{\mathrm{g} 4, \mathrm{co}}-C_{\mathrm{co}, \mathrm{b} 1}-C_{\mathrm{co}, \mathrm{b} 2}-C_{\mathrm{co}, \mathrm{b} 3}-C_{\mathrm{co}, \mathrm{b} 4}-C_{\mathrm{co}, \mathrm{wc}_{\mathrm{c}}} \\
C_{\mathrm{de}, \mathrm{do}}+C_{\mathrm{b} 1, \mathrm{do}}+C_{\mathrm{b} 2, \mathrm{do}}+C_{\mathrm{b} 3, \mathrm{do}}+C_{\mathrm{b}, \mathrm{do}}+C_{\mathrm{b} 5, \mathrm{do}}+C_{\mathrm{b} 6, \mathrm{do}}+C_{\mathrm{b} 7, \mathrm{do}}+C_{\mathrm{b} 8, \mathrm{do}}\end{array}$ & $=0$ & - \\
\hline & $\begin{array}{l}C_{\mathrm{de}, \mathrm{do}}+C_{\mathrm{b} 1, \mathrm{do} o}+C_{\mathrm{b} 2, \mathrm{do}}+C_{\mathrm{b} 3, \mathrm{do}}+C_{\mathrm{bd}, \mathrm{do}}+C_{\mathrm{bb}, \mathrm{do}}+C_{\mathrm{b} 6, \mathrm{do}}+C_{\mathrm{b} 7, \mathrm{do}}+C_{\mathrm{b} 8, \mathrm{do}} \\
+C_{\mathrm{g} 1, \mathrm{do}}+C_{\mathrm{g} 2, \mathrm{do}}+C_{\mathrm{g} 3, \mathrm{do}}+C_{\mathrm{g} 4 \mathrm{do}}-C_{\mathrm{do}, \mathrm{bs}}-C_{\mathrm{do}, \mathrm{b} 6}-C_{\mathrm{do}, \mathrm{b} 7}-C_{\mathrm{do}, \mathrm{b} 8}\end{array}$ & $=0$ & - \\
\hline C-detritus & $\begin{array}{l}C_{\mathrm{se}, \mathrm{de}}+C_{\mathrm{bl}, \mathrm{de}}+C_{\mathrm{b} 2, \mathrm{de}}+C_{\mathrm{b} 3, \mathrm{de}}+C_{\mathrm{b4}, \mathrm{de}}+C_{\mathrm{bs}, \mathrm{de}}+C_{\mathrm{br}, \mathrm{de}}+C_{\mathrm{b} 7, \mathrm{de}}+C_{\mathrm{b} 8 \mathrm{de}}+C_{\mathrm{g} 1, \mathrm{de}} \\
+C_{\mathrm{g} 2, \mathrm{de}}+C_{\mathrm{g} 3, \mathrm{de}}+C_{\mathrm{g} d, \mathrm{de}}-C_{\mathrm{de}, \mathrm{g} 1}-C_{\mathrm{de}, \mathrm{g} 2}-C_{\mathrm{de}, \mathrm{g} 3}-C_{\mathrm{de}, \mathrm{g} 4}-C_{\mathrm{de}, \mathrm{bu}}-C_{\mathrm{de}, \mathrm{do}}\end{array}$ & $=0$ & - \\
\hline \multicolumn{4}{|l|}{ Living compartments } \\
\hline Nitrifying bacteria (b1) & $N_{\text {nh.b1 }}-N_{b 1, \mathrm{nh}}-N_{\mathrm{b} 1, \mathrm{do}}-N_{\mathrm{b} 1, \mathrm{de}}-N_{\mathrm{b} 1, \mathrm{~g} 2}-N_{\mathrm{b} 1, \mathrm{~g} 3}-N_{\mathrm{b} 1, \mathrm{~g} 4}$ & $=0$ & - \\
\hline Nitrifying bacteria (b2) & $N_{\mathrm{nh}, \mathrm{b} 2}-N_{\mathrm{b} 2, \mathrm{nh}}-N_{\mathrm{b} 2, \mathrm{do}}-N_{\mathrm{b} 2, \mathrm{de}}-N_{\mathrm{b} 2, \mathrm{~g} 2}-N_{\mathrm{b} 2, \mathrm{~g} 3}-N_{\mathrm{b} 2, \mathrm{~g} 4}$ & $=0$ & - \\
\hline Ferrous-oxidizing bacteria (b3) & $N_{\mathrm{nh}, \mathrm{b} 3}-N_{\mathrm{b} 3, \mathrm{nh}}-N_{\mathrm{b} 3, \mathrm{do}}-N_{\mathrm{b} 3, \mathrm{de}}-N_{\mathrm{b} 3, \mathrm{~g} 2}-N_{\mathrm{b} 3, \mathrm{~g} 33}-N_{\mathrm{b} 3, \mathrm{~g} 4}$ & $=0$ & - \\
\hline Sulfide-oxidizing bacteria (b4) & $N_{\mathrm{nh}, \mathrm{b} 4}-N_{\mathrm{b} 4, \mathrm{nh}}-N_{\mathrm{b} 4, \mathrm{do}}-N_{\mathrm{b} 4 \mathrm{de}}-N_{\mathrm{b} 4, \mathrm{~g} 2}-N_{\mathrm{b} 4, \mathrm{~g} 33}-N_{\mathrm{bA}, \mathrm{g} 4}$ & $=0$ & - \\
\hline Heterotrophic bacteria (b5) & $N_{\text {nh,bs }}+N_{\text {do,b5 }}-N_{b 5, n h}-N_{b 5, d o}-N_{b 5, d e}-N_{b 5, q, 2}-N_{b 5, g 3}-N_{b 5, g 4}$ & $=0$ & - \\
\hline Denitrifying bacteria (b6) & 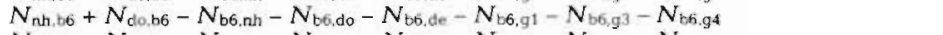 & $=0$ & - \\
\hline Sulfate-reducing bacteria (b7) & $N_{\mathrm{nh}, \mathrm{b} 7}+N_{\mathrm{do}, \mathrm{b} 7}-N_{\mathrm{b} 7, \mathrm{nh}}-N_{\mathrm{b} 7, \mathrm{do}}-N_{\mathrm{b} 7, \mathrm{de}}-N_{\mathrm{b}, \mathrm{g} 1}-N_{\mathrm{b} 7, \mathrm{~g} 3}-N_{\mathrm{b} 7,9 \mathrm{~g}}$ & $=0$ & - \\
\hline Ferric-reducing bacteria (b8) & $N_{\mathrm{nh}, \mathrm{b} 8}+N_{\mathrm{do}, \mathrm{b} 8}-N_{\mathrm{b} 8, \mathrm{nh}}-N_{\mathrm{b} 8, \mathrm{do}}-N_{\mathrm{bs}, \mathrm{de}}-N_{\mathrm{b} 8, \mathrm{~g} 1}-N_{\mathrm{b} 8, \mathrm{~g} 3}-N_{\mathrm{b} 8, \mathrm{~g} 4}$ & $=0$ & - \\
\hline Microfauna (anaerobic) (g1) & $N_{\text {de, } 11}+N_{\mathrm{b} b, g 1} N_{\mathrm{b} 7, \mathrm{~g} 1}+N_{\mathrm{b} 8, \mathrm{~g} 1}+N_{\mathrm{de}, \mathrm{g} 1}-N_{\mathrm{gl}, \mathrm{nh}}-N_{\mathrm{g} 1, \mathrm{do}}-N_{\mathrm{gl}, \mathrm{de}}=N_{\mathrm{gl}, \mathrm{g} 3}-N_{\mathrm{gl} 1, \mathrm{~g} 4}$ & $=0$ & - \\
\hline Microfauna (aerobic) (g2) & $\begin{array}{l}N_{\mathrm{de}, \mathrm{g} 2}+N_{\mathrm{b} 1, \mathrm{~g} 2}+N_{\mathrm{b} 2, \mathrm{~g} 2}+N_{\mathrm{b} 3, \mathrm{~g} 2}+N_{\mathrm{b}, \mathrm{g} 2}+N_{\mathrm{b}, \mathrm{g} 2}-N_{\mathrm{g} 2, \mathrm{nh}} \\
-N_{\mathrm{gg} 2, \mathrm{do}}-N_{\mathrm{g} 2, \mathrm{de}}-N_{\mathrm{g} 2, \mathrm{~g} 3}-N_{\mathrm{g} 2, \mathrm{~g} 4}\end{array}$ & $=0$ & - \\
\hline Meiofauna (g3) & 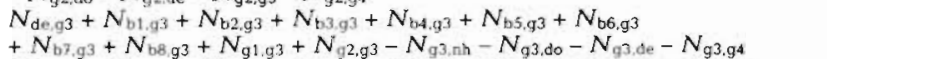 & $=0$ & - \\
\hline Macrofauna (g4) & & & \\
\hline & $+N_{\mathrm{bB}, \mathrm{g}^{4}}+N_{\mathrm{g} 1, \mathrm{~g} 4}+N_{\mathrm{g} 2, \mathrm{~g} 4}+N_{\mathrm{g} 3, \mathrm{~g}^{4}}-N_{\mathrm{g} 4, \mathrm{nh}}-N_{\mathrm{g} 4, \mathrm{do}}-N_{\mathrm{g} 4, \mathrm{de}}-N_{\mathrm{g} 4, \mathrm{~g}^{5}}$ & $=0$ & - \\
\hline Nitrifying bacteria (b1) & 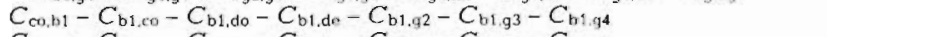 & $=0$ & - \\
\hline Nitrifying bacteria (b2) & $C_{\mathrm{co,b} 2}-C_{\mathrm{b} 2, \mathrm{o} 0}-C_{\mathrm{b} 2, \mathrm{do}}-C_{\mathrm{b} 2 \mathrm{de}}=C_{\mathrm{b} 2, \mathrm{~g} 2}-C_{\mathrm{b} 2,93}-C_{\mathrm{b} 2, \mathrm{~g} 4}$ & $=0$ & - \\
\hline Ferrous-oxidizing bacteria (b3) & $C_{\mathrm{co}, \mathrm{b} 3}-C_{\mathrm{b} 3, \mathrm{co}}-C_{\mathrm{b} 3, \mathrm{do}}-C_{\mathrm{b} 3, \mathrm{de}}-C_{\mathrm{b} 3, \mathrm{~g} 2}-C_{\mathrm{b} 3, \mathrm{~g} 3 \mathrm{3}}-C_{\mathrm{b} 3, \mathrm{gA}}$ & $=0$ & - \\
\hline Sulfide-oxidizing bacteria (b4) & 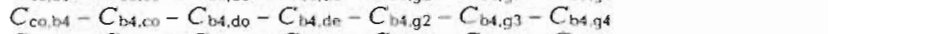 & $=0$ & - \\
\hline Heterotropic bacteria (b5) & 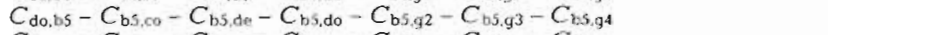 & $=0$ & - \\
\hline Denitrifying bacteria (b6) & 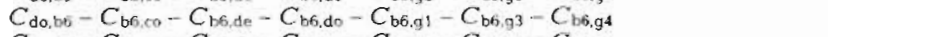 & $=0$ & - \\
\hline Sulfate-reducing bacteria (b7) & $C_{d 0, b 7}-C_{b 7, c 0}-C_{b 7, d e}-C_{b 7, d o}-C_{b 7, g 1}-C_{b 7,93}-C_{b 7, g^{4}}$ & $=0$ & - \\
\hline Ferric reducing bacteria $(\mathrm{b} 8)$ & $C_{d \sigma, b 3}-C_{b 8, c o}-C_{b 8, d e}-C_{b 8, d o}-C_{b 8, g_{1}}-C_{b 8, g^{3}}-C_{b 8, g^{4}}$ & $=0$ & - \\
\hline Microfauna (anaerobic) (g1) & $C_{b 6, g 1}+C_{b 7, g 1}+C_{g 8, g 1}+C_{d e, g t}-C_{g 1, c o}-C_{g 1, d o}-C_{g 1, d e}-C_{g 1, g 3}-C_{g 1, g 4}$ & $=0$ & - \\
\hline Microfauna (aerobic) (g2) & $\begin{array}{l}C_{b 1, g 2}+C_{b 2, g 2}+C_{b 3, g 2}+C_{b 4, g 2}+C_{b 5, g 2} \\
+C_{d e, g 2}-C_{g 2, c o}-C_{g 2, d o}-C_{g 2, d e}-C_{g 2, g 3}-C_{g 2, g 4}\end{array}$ & $=0$ & - \\
\hline Meiofauna (g3) & 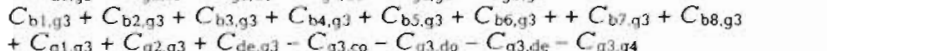 & $=0$ & - \\
\hline Macrofauna (g4) & 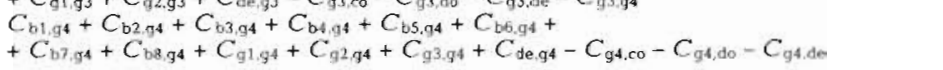 & $=0$ & - \\
\hline \multicolumn{4}{|c|}{ Equations describing $\mathrm{C}: \mathrm{N}$ relationships } \\
\hline $\mathrm{N}: \mathrm{C}$ of bacteria going to detritus & for $x=\mathrm{b} 1, \mathrm{~b} 2, \ldots \mathrm{b} 8$ & & $(1,2,5)$ \\
\hline $\mathrm{N}: \mathrm{C}$ of grazers going to detritus & for $x=g 1, g 2, \ldots b 4$ & & $(1,2,5)$ \\
\hline $\mathrm{N}: \mathrm{C}$ of bactena going to $\mathrm{g} 1$ & $R_{x} C_{x, g 1}-N_{x, g t}=0$ & & $(1,2,5)$ \\
\hline$N: C$ of bacteria going to g2 & for $x=\mathrm{b} 1, \mathrm{~b} 2, \ldots \mathrm{b} 5$ & & $(1,2,5)$ \\
\hline $\mathrm{N}: \mathrm{C}$ of bacteria going to $\mathrm{g} 3$ & for $x=b 1, b 2, \ldots b 8$ & & $(1,2,5)$ \\
\hline $\mathrm{N}: \mathrm{C}$ of bacteria going to $\mathrm{g}^{4}$ & for $x=b 1, b 2, \ldots b 8$ & & $(1,2,5)$ \\
\hline$N: C$ of grazers going to g3 & $R_{x} C_{x, 94}-N_{x, 93}=0$ & & $(1,2,5)$ \\
\hline$N: C$ of grazers going to $\mathrm{g} 4$ & for $x=g 1, g 2, g 3$ & & $(1,2,5)$ \\
\hline
\end{tabular}




\begin{tabular}{|c|c|c|c|c|}
\hline Description & \multicolumn{3}{|l|}{ Equation } & Source \\
\hline \multicolumn{5}{|c|}{ Equations describing inorganic stoichometric relationships } \\
\hline $\mathrm{Fe}: \mathrm{S}$ precipitation & $F e_{12, \text { fes }}-S_{\text {s2 2, fes }}$ & $=0$ & & $(6)$ \\
\hline $\mathrm{O}_{2}+\mathrm{NH}_{3}$ combine to $\mathrm{NO}_{2}$ & $O^{b} t_{02, n 5}-1.5 N^{b 1} t_{n i n} 5$ & $=0$ & & (6) \\
\hline $\mathrm{O}_{2}+\mathrm{NO}_{2}^{-}$combine to $\mathrm{NO}_{3}$ & 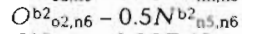 & $=0$ & & (6) \\
\hline $\mathrm{O}_{2}+\mathrm{Fe}^{2+}$ combine to $\mathrm{Fe}^{3+}$ & 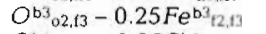 & $=0$ & & (6) \\
\hline $\mathrm{O}_{2}+\mathrm{S}^{2-}$ combine to $\mathrm{SO}_{4}{ }^{2-}$ & $\mathrm{O}^{\mathrm{b} 4} 02.53-0.25 \mathrm{~S}^{\mathrm{b} 4} \mathrm{~s} 2.53$ & $=0$ & & (6) \\
\hline \multicolumn{5}{|c|}{ Data equations for Santa Monica Basin } \\
\hline $\mathrm{O}_{2}$ exchange & $O_{\mathrm{wc}, 02}$ & $=-0.36$ & & (7) \\
\hline $\mathrm{NO}_{3}^{-}$exchange & $N_{\text {wC, no }}$ & $=-6.27$ & & (7) \\
\hline $\mathrm{SO}_{4}{ }^{2-}$ exchange & Swes3 & $=-0.40$ & & (7) \\
\hline $\mathrm{TCO}_{2}$ exchange & $C_{c o, w c}$ & $=2.7$ & & (7) \\
\hline C edimentation & $C_{\text {sede }}$ & $=3.67$ & & (7) \\
\hline$N$ sedimentation & $N_{\text {sed de }}$ & $=0.31$ & & (7) \\
\hline Macrofaunal respiration & $C_{g 4, c 0}-C_{g^{4}} A_{\text {mar }} T_{i}$ & $\geq 0$ & & $(8,23)$ \\
\hline $\mathrm{C}: \mathrm{N}$ burial, $\min$ & $R_{\text {pom }} C_{\text {de.bu }}-N_{\text {de,bu }}$ & $\geq 0$ & & (9) \\
\hline $\mathrm{C}: \mathrm{N}$ of POM flux to detritus & $R_{\text {sed }} C_{\text {se,de }}-N_{\text {se,de }}$ & $=0$ & & (7) \\
\hline \multicolumn{5}{|c|}{ Data equations and constraints for Patton Escarpment } \\
\hline $\mathrm{O}_{2}$ exchange & $O_{w c, 02}$ & & $=-1.2$ & $\{10\}$ \\
\hline $\mathrm{NO}_{3}$ exchange & $N_{\text {we,nt }}$ & & $=-0.0548$ & $(11,12)$ \\
\hline C burial & $C_{\text {de,bu }}$ & & $=0.11$ & (25) \\
\hline C sedimentation & $C_{\text {se,de }}$ & & $\geq 0.26$ & (15) \\
\hline$N$ edimentation & \multirow{3}{*}{\multicolumn{2}{|c|}{ 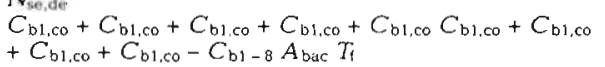 }} & $\geq 0.026$ & (12) \\
\hline \multirow[t]{2}{*}{ Bacteria respiration } & & & & \\
\hline & & & $\geq 0$ & $(11,16,23)$ \\
\hline Microfauna respiration & \multirow{2}{*}{\multicolumn{2}{|c|}{$C_{g 1, c 0}+C_{g 2, c 0}-C_{g 1-2} A_{p r o} T_{i}$}} & $\geq 0$ & $(11,16,23)$ \\
\hline Meiofauna respiration & \multirow{2}{*}{\multicolumn{2}{|c|}{ 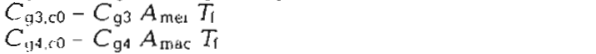 }} & $\geq 0$ & $(11,16,23)$ \\
\hline Macrofauna respiration & & & $\geq 0$ & $(11,16,23)$ \\
\hline $\mathrm{C}: \mathrm{N}$ burial, min & \multicolumn{2}{|l|}{$R_{\text {pord }} C_{\text {de, bu }}-N_{\text {de,bu }}$} & $\geq 0$ & (15) \\
\hline
\end{tabular}

\section{Constraint relationships}

Additional constraint requires all flows to be greater than 0 . The following constraint relationships assume that the organic substrates have a redox state between that of a lipid $(-2)$ and that of a polysaccharide $(0)$. Production efficiency is for gross production.

C. N nit bacteria,

C: N nit. bacteria, max

$\mathrm{C}: \mathrm{S}$ sulfate bacteria, min

C:S sulfate bacteria, max

C: Fe ferric bacteria, max

C: Fe ferric bacteria, max

$\mathrm{NO}_{2}^{-}: \mathrm{CO}_{2}$ nitrifying bacteria, min

$\mathrm{NO}_{3}^{-}: \mathrm{CO}_{2}$ nitrifying bacteria, min

$\mathrm{Fe}^{3+}: \mathrm{CO}_{2}$ nitrifying bacteria, min

$\mathrm{SO}_{4}{ }^{2-}: \mathrm{CO}_{2}$ nitrifying bacteria, min

Net-production eff. (b5), $\mathrm{min}$

Net-production eff. (b5), max

Net-production eff. (b6), min

Net-production eff. (b6), max

Net-production eff. (b7), $\mathrm{min}$

Net-production eff. (b7), max

Net-production eff. (b8), max

Excretion (g1), min

Excretion (g2), min

Excretion (g3), min

Excretion (g4), min

Excretion (g1), max

Excretion (g2), max

Excretion ( 33 ), max

Excretion (g4), max

Assimilation efficiency ( $\mathrm{g} 1)$, min

Assimilation efficiency ( $\mathrm{g} 1$ ), $\max$

Assimilation efficiency ( $g 2)$, min

Assimilation efficiency ( $g 2$ ), $\max$

Assimilation efficiency (g3), $\mathrm{min}$

Assimilation efficiency ( $g 3$ ), max

Assimilation efficiency ( $(\mathrm{g} 4)$, $\mathrm{min}$

Assimilation efficiency $(\mathrm{g} 4)$, max

Production efficiency (g1), min

Production efficiency ( $\mathrm{g} 1$ ), max

Production efficiency ( $\mathrm{g} 2)$, min

Production efficiency (g2), $\max$

Production efficiency ( $\mathrm{g} 3), \mathrm{min}$

Production efficiency (g3), $\max$

Production efficiency ( $g 4), \max$

$C_{\text {br.co }}$

$C_{b 6 . c 0}$
$-C_{b 6,00}$

$C_{b 7, c b}$

$-C_{\mathrm{b} 7 . \mathrm{co}}$

$C_{\mathrm{b} 7, \mathrm{CO}}$

$-C_{\mathrm{bt} C 0}$

$-C_{\text {co,bl }}$

$-C_{\mathrm{co,b} 3}$

$-C_{\mathrm{co}, \mathrm{b} 3}$
$-C_{\mathrm{co}, \mathrm{b} 4}$

$0.9 C_{\text {do.bs }}$

$-0.4 C_{\text {do.b5 }}$

$0.95 C_{\text {do,b } 6}$

$-0.58 C_{\text {do. bo }}$

$0.95 C_{d o b}$ ?

$-0.7 C_{\mathrm{do} b \mathrm{~b}}$

$-0.9 C_{d o, b 9}$

Cgi,do

$C_{\text {g2 do }}$

$C_{\mathrm{g} 3, \mathrm{do}}$

$C_{94, d o}$

- $C_{\text {gi,do }}$

- $C_{\mathrm{g} 2 \text {,do }}$

$-C_{93, \mathrm{do}}$

$-0.8 N^{\mathrm{bG}}{ }^{\mathrm{n} 5 \mathrm{n}, \mathrm{n} 2}$

$+1.25 N^{100} \mathrm{~ns}^{102}$

$-1.33 S^{67} \mathrm{~s} 3 . \mathrm{s} 2$

$+2 S^{67}{ }^{63,5}$

$-0.20 F^{\mathrm{b8}}$

$+0.25 F^{\mathrm{b} 8} 13.12$
$+0.028 \mathrm{~N}^{\mathrm{bl}}$

$+0.01 N^{\mathrm{b} 2} \mathrm{n}_{\mathrm{n}, \mathrm{n} 6}$

$+0.01 F^{\mathrm{b3}} 12.13$

$+0.1 S^{b 4}{ }_{n 5, n 6}$

$-C_{\mathrm{b} 5, \mathrm{cO}}$

$+C_{b 5 . c 0}$

$-C_{b 6 . c 0}-C_{b 6}$

$+C_{b 6, c 0}+C_{b 6, d o}$

$+C_{b 6, \mathrm{co}}+C_{b 6, d o}$
$-C_{b 7, \mathrm{co}}-C_{b 7, d o}$

$+C_{\mathrm{b} 7, \mathrm{CO}}+C_{\mathrm{b} \gamma, \mathrm{do}}$

$+C_{\mathrm{b} 9, \mathrm{CO}}+C_{\mathrm{b8}, \mathrm{do}}$

$-0.33 C_{\mathrm{g} 1, \mathrm{c} 0}$

$-0.33 C_{g 2,50}$

$-0.33 C_{93,00}$

$-0.33 C_{04,00}$

$+C_{g 1.60}$

$+C_{\mathrm{g} 2, \mathrm{CO}}$

$-C_{g 4 . d o}$

$+C_{\mathrm{g} 3, \mathrm{co}}$

$5 C_{b 6, g 1}+0.5 C_{b 7 . g 1}+0.5 C_{b 8, g 1}+0.5 C_{d e, g 1}-C_{g 1 . d e}$

$-0.1 C_{b 6, g 1}-0.1 C_{b 7, g 1}-0.1 C_{b 8, g 1}-0.1 C_{d e g 1}+C_{g 1 d e}$

$0.5 C_{b 1, g 2}+0.5 C_{b 2, g 2}+0.5 C_{b 3 ., 2}+0.5 C_{b 4.92}+0.5 C_{b 5, g^{2}}+0.5 C_{\text {de.g2 }}-C_{\mathrm{g} 2, \mathrm{de}}$

$-0.1 C_{b 1.92}-0.1 C_{b 2,92}-0.1 C_{b 3 . g 2}-0.1 C_{b 4, g 2}-0.1 C_{b 5, g 2}-0.1 C_{d e, g 2}+C_{\mathrm{g}^{2} \text {,de }}$

$0.5 C_{b 1 . g 3}+0.5 C_{b 2, g 3}+0.5 C_{b 3 . g 3}+0.5 C_{b 4 . g 3}+0.5 C_{b 5 . g 3}$

$0.5 C_{b 6.93}+0.5 C_{b 7.93}+0.5 C_{b 8,93}+0.5 C_{g_{1.93}}+0.5 C_{g 2.93}+0.5 C_{d e . g 3}-C_{g 3 . d e}$

$-0.1 C_{b 1, g 3}-0.1 C_{b 2 . g 3}-0.1 C_{b 3,43}-0.1 C_{b 4,93}-0.1 C_{b 5, g 3}-0.1 C_{b 6}$

$0.5 C_{b l . g 4}+0.5 C_{b 2, g 4}+0.5 C_{b 3,94}+0.5 C_{b 4, g 4}+0.5 C_{b 5, g 4}+0.5 C_{b 6, g 4}+0.5 C_{b 7, g 4}$

$+0.5 C_{\text {b8.g4 }}+0.5 C_{g 1, g 4}+0.5 C_{g^{2 . g 4}}+0.5 C_{g 3 . g 4}+0.5 C_{\text {de.g3 }}-C_{g 4 . d e}$

$-0.1 C_{b 1,94}-0.1 C_{b 2, g 4}-0.1 C_{b 3, q 4}-0.1 C_{b 4.94}-0.1 C_{b 5,94}-0.1 C_{b 6.94}$

$-0.1 C_{b 7, g 4}-0.1 C_{b 8, g 4}-0.1 C_{g 1, g 4}-0.1 C_{g 2, g 4}-0.1 C_{g 3 . g 4}-0.1 C_{d e . g 3}+C_{g 4 . d e} \geq 0$

$-C_{g 1, c o}-C_{g 1, d e}-C_{g 1, d o}+0.9 C_{b 6, g 1}+0.9 C_{b 7, q 1}+0.9 C_{b 8, g 1}+0.9 C_{d e, g}$.

$C_{\mathrm{g} 1 . \mathrm{co}}+C_{\mathrm{g} 1 . \mathrm{de}}+C_{\mathrm{gl}, \mathrm{do}}-0.4 C_{\mathrm{b} 6, \mathrm{~g} 1}-0.4 C_{\mathrm{b} 7, \mathrm{gl}}-0.4 C_{\mathrm{b} 8, \mathrm{gl}}-0.4 C_{\mathrm{de} . \mathrm{g} 1}$

$-C_{\mathrm{g} 2, \mathrm{co}}-C_{\mathrm{g} 2, \mathrm{de}}-C_{\mathrm{g} 2, \mathrm{do}}+0.9 C_{\mathrm{b} 1 . \mathrm{g} 2}+0.9 C_{\mathrm{b} 2, \mathrm{~g} 2}$

$+0.9 C_{b 3.92}+0.9 C_{b 4, g^{2}}+0.9 C_{b 5, g^{2}}+0.9 C_{d e, g 2}$

$C_{g 2, \mathrm{co}}+C_{\mathrm{g} 2, \mathrm{de}}+C_{\mathrm{g} 2, \mathrm{do}}-0.4 C_{\mathrm{b} 1, \mathrm{~g} 2}-0.4 C_{\mathrm{b} 2, \mathrm{~g}^{2}}$

$-0.4 C_{\mathrm{b} 3 . \mathrm{g} 2}-0.4 C_{\mathrm{b} 4, \mathrm{~g} 2}-0.4 C_{\mathrm{bs}, \mathrm{g} 2}-0.4 C_{\mathrm{de}, \mathrm{g} 2}$

- $C_{\mathrm{g} 3, \mathrm{Co}}-C_{\mathrm{g} 3, \mathrm{de}}-C_{\mathrm{g} 3, \mathrm{do}}+0.9 C_{\mathrm{b} 1, \mathrm{~g} 3}+0.9 C_{\mathrm{b} 2, \mathrm{~g} 3}+0.9 C_{\mathrm{b} 3, \mathrm{~g} 3}+0.9 C_{\mathrm{b} 4, \mathrm{~g} 3}$

$\geq 0 \quad(1,6)$

$\geq 0$

$\geq 0$

$\geq 0$

$\geq 0$

$\geq 0$

$\geq 0$

$\geq 0$

$\geq 0$

$\geq 0$

$+0.9 C_{b 5, g 3}+0.9 C_{b 6, g 3}+0.9 C_{b 7, g 3}+0.9 C_{b 8, g 3} 0.9 C_{g 1 . g 3}+0.9 C_{g 2.93}+0.9 C_{\text {deg }}$

$C_{g 3, c o}+C_{g 3, d e}+C_{g 3, d o}-0.4 C_{b 1, g 3}-0.4 C_{b 2, g 3}-0.4 C_{b 3, q 3}-0.4 C_{b 4, g 3}-0.4 C_{b 5, q 3}$

$-0.4 C_{b 6, g 3}-0.4 C_{b 7, g 3}-0.4 C_{b 8, g 3}-0.4 C_{g 1.93}-0.4 C_{g 2, g 3}-0.4 C_{\text {de.g2 }}$

$C_{g 4, c o}+C_{g 4 . d e}+C_{g 4, d o}-C_{b 1 . g 4}-0.6 C_{b 2 . g 4}-0.6 C_{b 3, g 4}-0.6 C_{b 4, g 4}-0.6 C_{b 5 . g 4}$

$-0.6 C_{b 6.94}-0.6 C_{b 7 . g 4}-0.6 C_{b 8 . g 4}-0.6 C_{g 1 . g 4}-0.6 C_{g 2 . g 4}-0.6 C_{g 3 . g 4}-0.6 C_{d e . g 4}$

- $C_{b 1,94}-C_{b 2,94}-C_{b 3,94}-C_{b 4.94}-C_{b 5.94}-C_{b 6.94}-C_{b 7.94}$

$-C_{\mathrm{b} 8, g 4}-C_{g 1,94}-C_{g 2, g 4}-C_{g 3, g 4}-C_{\mathrm{de}, \mathrm{g} 4}-C_{\text {mar }} I_{\mathrm{mar}} T f$
$-4.1 N_{x, \mathrm{de}}+C_{\mathrm{xde}} \quad \geq 0, \quad$ for $x=\mathrm{g} 1, \mathrm{~g} 2, \ldots \mathrm{g}$

$\begin{array}{lll}-4.1 N_{x, \text { de }}+C_{x, \text { de }} & \geq 0 & \text { for } x=\mathrm{g} 1, \mathrm{~g} 2, \ldots \mathrm{g} 4 \\ -4.1 N_{x, \text { do }}+C_{x, \mathrm{do}} & \geq 0 & \text { for } x=\mathrm{b} 1, \mathrm{~b} 2, . \mathrm{g} 4\end{array}$

$\geq 0 \quad$ for $x=b 1, b 2 \ldots$

$13 N_{x, \mathrm{nh}}+C_{x, \mathrm{co}} \quad \geq 0 \quad$ for $x=\mathrm{b} 1, \mathrm{~b} 2, \ldots \mathrm{g} 4$ 


\section{LITERATURE CITED}

Andersen, F. Ø., Kristensen, E. (1992). The importance of benthic macrofauna in decomposition of microalgae in a coastal marine sediment. Limnol. Oceanogr. 37: 1392-1403

Baas Becking, L. G. M., Parks, G. S. (1927). Energy relationships in the metabolism of autotrophic bacteria. Physiol Rev. 7: 85-106

Billen, G. (1978). A budget of nitrogen recycling in North Sea sediments off the Belgain coast. Estuar. coast. Mar. Sci. 7 . $127-146$

Børsheim, K. Y., Bratbak, G. C. (1987). Cell volume to cell carbon conversion factors for a bacterivorous Monas sp. enriched from seawater. Mar. Ecol. Prog. Ser. 36: 171-175

Cammen, L. M. (1980a). The significance of microbial carbon in the nutrition of the deposit feeding polychaete Nereis succinea. Mar. Biol. 61: 9-20

Cammen, L. M. (1980b). Ingestion rate: an empirical model for aquatic deposit feeders and detritivores. Oecologia 44 $303-310$

Cammen, L. M. (1989). The relationship between ingestion rate of deposit feeder and sediment nutrient value. In Lopez, G., Taghon, G., Levinton, J. (eds.) Coastal and estuarine studies. Springer-Verlag, Berlin, p. 201-222

Canfield, D. E. (1989). Sulfate reduction and oxic respiration in marine sediments: implications for organic carbon preservation in euxinic environments. Deep Sea Res. 36: 121-138

Canfield, D. E. (1991a). Aerobic sulfate reduction in microbial mats. Science 251: 1471-1473

Canfield, D. E. (1991b). Sulfate reduction in deep-sea sedi. ments. Am. J. Sci. 291: 177-188

Carey, D. A., Mayer, L. M. (1990). Nutrient uptake by a deposit-feeding enteropneust: nitrogenous sources. Mar. Ecol. Prog. Ser. 63: 79-84

Deming, J. W., Yager P. L. (1992). Natural bacterial assemblages in deep-sea sediments: towards a global view. In: Rowe, T., Pariente, V. (eds.) Deep-sea food chains and the global carbon cycle. Kluwer Academic Publishers, Amsterdam, p. 11-27

Ducklow, H. W., Fasham, M. J. R., Vézina, A. F. (1989). Derivation and analysis of flow networks for open ocean plankton systems. In: Wulff, F., Field, J. G., Mann, K. H. (eds.) Network analysis in marine ecology. Springer-Verlag, Berlin, p. $159-205$

Eldridge, P. M., Jackson, G. A. (1992). Benthic food web flows in the Santa Monica Basin estimated using inverse methodology. In: Rowe, T., Pariente, V. (eds.) Deep-sea food chains and the global carbon cycle. Kluwer Academic Publishers, Amsterdam, p. 255-276

Fasham, M. J. R., Ducklow, H. W., McKelvie, S. M. (1990). A nitrogen-based model of plankton dynamics in the oceanic mixed layer. J. mar. Res. 48: 591-639

Fenchel, T. (1987). Ecology of protozoa: the biology of freeliving phagotrophic protists. Science Tech Publishers, Springer-Verlag, Berlin

Fenchel, T., Blackburn, T. H. (1979). Bacteria and mineral cycling Academic Press, London

Fenchel, T., Finlay, B. J. (1991). The biology of free-living anaerobic ciliates. Eur. J. Protistol. 26: 201-215

Finlay, B. J., Uhlig, G. (1981). Calorific and carbon values of marine and freshwater protozoa. Helgoländer Meeresunters. $34: 401-412$

Hanson, R. J., Haskell, K. R. (1982). Two algorithms for the linearly constrained least squares problem. A.CM Trans. Math Software 8: 323-333

Haskell, K. H., Hanson, R. J (1981). An algorithm for linear least squares problems with equality and nonnegativity constraints. Math. Program. 21: 98-118

Hooper, A. B. (1989). Biochemistry of the nitrifying lithoautotrophic bacteria. In: Schlegel, H. G., Bowien, B. (eds.) Autotrophic bacteria. Springer-Verlag, Berlin, p. 239-266

Jackson, G. A., Azam, F., Carlucci, A. F., Eppley, R. W. Williams, P. M., Finney, B., Huh, C., Small, L. F., Gorsline, D. S., Hickey, B., Jahnke, R. A., Kaplan, I. R., Venkatesan, M. I., Landry, M. R., Wong, K. M. (1989). Elemental cycling and fluxes off southern California. EOS 70: 146-149

Jackson, G. A., Eldridge, P. M. (1992). Foodweb analysis of a planktonic system off southern California. Prog. Oceanogr. 30: $223-251$

Jahnke, R. A. (1990). Early diagenesis and recyling of biogenic debris at the seafloor, Santa Monica Basin, California. J. mar. Res. 48: 413-436

Jahnke, R A., Reimers, C. E., Craven, D. B. (1990). Intensification of recycling of organic matter at the seafloor near ocean margins. Nature 348: 50-54

Jorgensen, B. B. (1977). Bacterial sulfate reduction within reduced microniches of oxidized sediments. Mar. Biol. 41: $7-17$

Jørgensen, B. B. (1982). Mineralization of organic matter in the sea bed - the role of sulfate reduction. Nature 296 : $643-645$

Jørgensen, B. B. (1983). Processes at the sediment-water interface. In: Bolin, D., Cook, R. B. (eds.) The major biogeochemical cycles and their interactions. Wiley, Chichester, p. 477-509

Jørgensen, B. B. (1989). Biogeochemisty of chemoautotrophic bacteria. In: Schlegal, H. H., Bowien, B. (eds.) Autotrophic bacteria. Springer-Verlag, Berlin, p. 117-146

Kelly, D. P. (1989). Physiology and biochemistry of unicellular sulfur bacteria. In: Schegel, H. G., Bowien, B. (eds.) Autotrophic bacteria. Springer-Verlag, Berlin, p. 193-218

Kemp, P. F. (1987). Potential impact on bacteria of grazing by a macrofaunal deposit-feeder, and the fate of bacterial production. Mar. Ecol. Prog. Ser. 36: 151-161

Kristensen, E. (1985). Oxygen and inorganic nitrogen exchange in a Nereis virens (Polychaeta) bioturbated sediment-water system. J. coast. Res. 1: 109-116

Kristensen, E., Blackburn, T. H. (1987). The fate of organic carbon and nitrogen in experimental marine sediments: influence of bioturbation and anoxia. J. mar. Res. 45: 231-257

Lawson, C. L., Hanson, R. J. (1974). Solving least squares problems. Prentice Hall, Englewood Cliffs

Lee, C. (1992). Controls on organic carbon preservation: the use of stratified water bodies to compare intrinsic rates of decomposition in oxic and anoxic systems. Geochim. Cosmochim. Acta 56: 3323-3335

Levinton, J. S. (1989). Deposit feeding and coastal oceanography. In: Lopez, G., Taghon, G., Levinton, J. (eds.) Coastal and estuarine studies. Springer-Verlag, New York, p. 1-23

Lopez, G. (1989). Radiotracer methods for determining utilization of sedimentary organic matter by deposit feeders. In: Lopez, G., Taghon, G., Levinton, J. (eds.) Coastal and estuarine studies. Springer-Verlag, New York, p. 149-170

Lovley, D. R., Phillips, E. J. P. (1989). Requirement for a microbial consortium to completely oxidize glucose in Fe(III)-reducing sediments. Appl. environ. Microbiol. 54: $3234-3236$

Moore, T. C., Burckle, L. H., Geitznauer, K., Luz, B., MolinaCruz, A., Robertson, J. H., Szchs, H., Sancetta, C., Theide, J., Thompson, P., Wenkam, C. (1980). The reconstruction of sea surface temperatures in the Pacific Ocean of 18,000 B. P. Mar. Micropaleontol. 5: 215-247

Nagata, T (1986). Carbon and nitrogen content of natural planktonic bacteria. Appl. environ. Microbiol. 52: 28-32 
Platt, T., Lewis, M., Geider, R. (1984). Thermodynamics of the pelagic ecosystem: Elementary closure conditions for biological production in the open ocean. In: Fasham, M. J. R. (ed.) Flows of energy and materials in marine ecosystems. Plenum, New York, p. 49-84

Reimers, C. E. (1987). An in situ microprofiling instrument for measuring interfacial pore water gradients: method and oxygen profiles from the North Pacific Ocean. Deep Sea Res. 34: 2019-2035

Reimers, C. E., Smith, K. L. (1986). Reconciling measured and predicted fluxes of oxygen across the deep sea sedimentwater interface. Limnol. Oceanogr. 31: 305-318

Rowe, G. T. (1983). Biomass and production of the deep-sea macrobenthos. In: Rowe, G. T. (ed.) The sea, Vol. 8. Wiley, New York, p. 97-121

Smith, K. L. (1987). Food energy supply and demand: A discrepancy between particulate organic carbon flux and sediment community oxygen consumption in the deep ocean. Limnol. Oceanogr. 32: 201-220

Smith, K. L., Baldwin, R. L., Williams, P. M. (1992). Reconciling particulate organic carbon flux and sediment community oxygen consumption in the deep North Pacific. Nature 259: 313-316

Smith, K. L., Laver, M. B., Brown, N. O. (1983). Sediment oxygen consumption and nutrient exchange in the central and eastern North Pacific. Limnol. Oceanogr. 28: 882-898

Snider, L. J., Burnett, B. R., Hessler, R. R. (1984). The composition and distribution of meiofauna and nanobiota in a central North Pacific deep-sea area. Deep Sea. Res. 31: $1225-1249$

Stouthamer, A. H. (1988). Dissimilatory reduction of oxidized nitrogen compounds. In: Zehnder, A. J. B. (ed.) Biology of anaerobic microorganisms. Wiley, New York, p. 245-304

Stumm, W., Morgan, J. J. (1981). Aquatic chemistry, 2nd edn. Wiley, New York

Sweeney, R. E., Kalil, E. K., Kaplan, I. R. (1980). Characterization of domestic and industrial sewage in Southern California coastal sediments using nitrogen, carbon, sulfur

This article was submitted to the editor and uranium tracers, Mar. environ. Res. 3: 225-243

Thode-Andersen, S., Jørgensen, B. B. (1989). Sulfate reduction and the formation of ${ }^{35} \mathrm{~S}$-labeled $\mathrm{FeS}, \mathrm{FeS}_{2}$, and $\mathrm{S}^{0}$ in coastal marine sediments. Limnol. Oceanogr. 34 $793-806$

Thompson, B., Dixon, J., Schroeter, S., Reish, D. J. (1990). Ecology of the Southern California Bight. A synthesis and interpretation, Vol. 2. Ocean Studies Institute, California State University, Long Beach

Tiedje, J. M. (1988). Ecology of denitrification and dissimilatory nitrate reduction to ammonium. In: Zehnder, A. J. B. (ed.) Biology of anaerobic microorganisms. Wiley, New York, p. 179-244

Toth, D. J., Lerman, A. (1977). Organic matter reactivity and sedimentation rates in the ocean. Am. J. Sci. 277: 465-485

Vézina, A. F., Platt, T. (1988). Food web dynamics in the ocean. I. Best-estimates of flow networks using inverse methods. Mar. Ecol. Prog. Ser. 42: 269-287

Wenkam, C. (1976). Late quaternary changes in the oceanography of the eastern tropical Pacific. M.Sc. thesis, Oregon State University, Corvallis

Wetzel, R. L. (1977). Carbon resources of a benthic salt marsh invertebrate Nassarius obsoletus (Mollusca: Nassariidae) In: Wiley, M. (ed.) Estuarine processes, Vol. 2. Academic Press, New York, p. 293-308

Widdel, F. (1988). Microbiology and ecology of sulfate- and sulfur-reducing bacteria. In: Zehnder, A. J. (ed.) Biology of anaerobic microorganisms. Wiley, New York, p. 469-585

Wishner, K., Levin, L., Gowing, M., Mullineaux, L. (1990). Involvement of the oxygen minimum in benthic zonation on a deep seamount. Nature 346: 57-69

Yoon, W. B., Benner, R. (1992). Denitrification and oxygen consumption in sediments of two south Texas estuaries. Mar. Ecol. Prog. Ser. 90: 157-167

Zehnder, A. J. B., Stumm, W. (1988). Geochemistry and biogeochemistry of anaerobic habitats. In: Zehnder, A. J. B. (ed.) Biology of anaerobic microorganisms. Wiley, New York, p. 1-38

Manuscript first received: December 21, 1992

Revised version accepted: June 11, 1993 